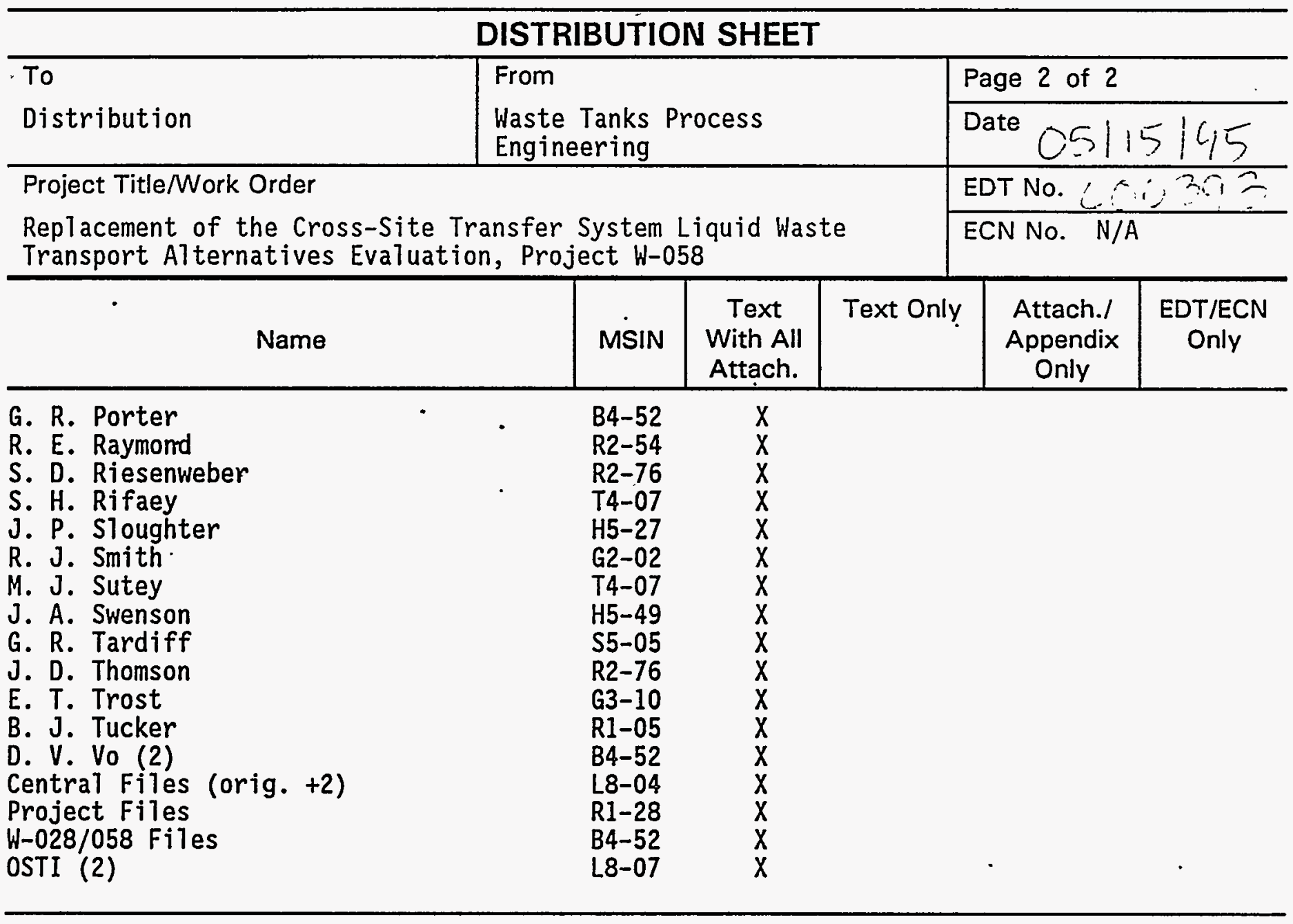




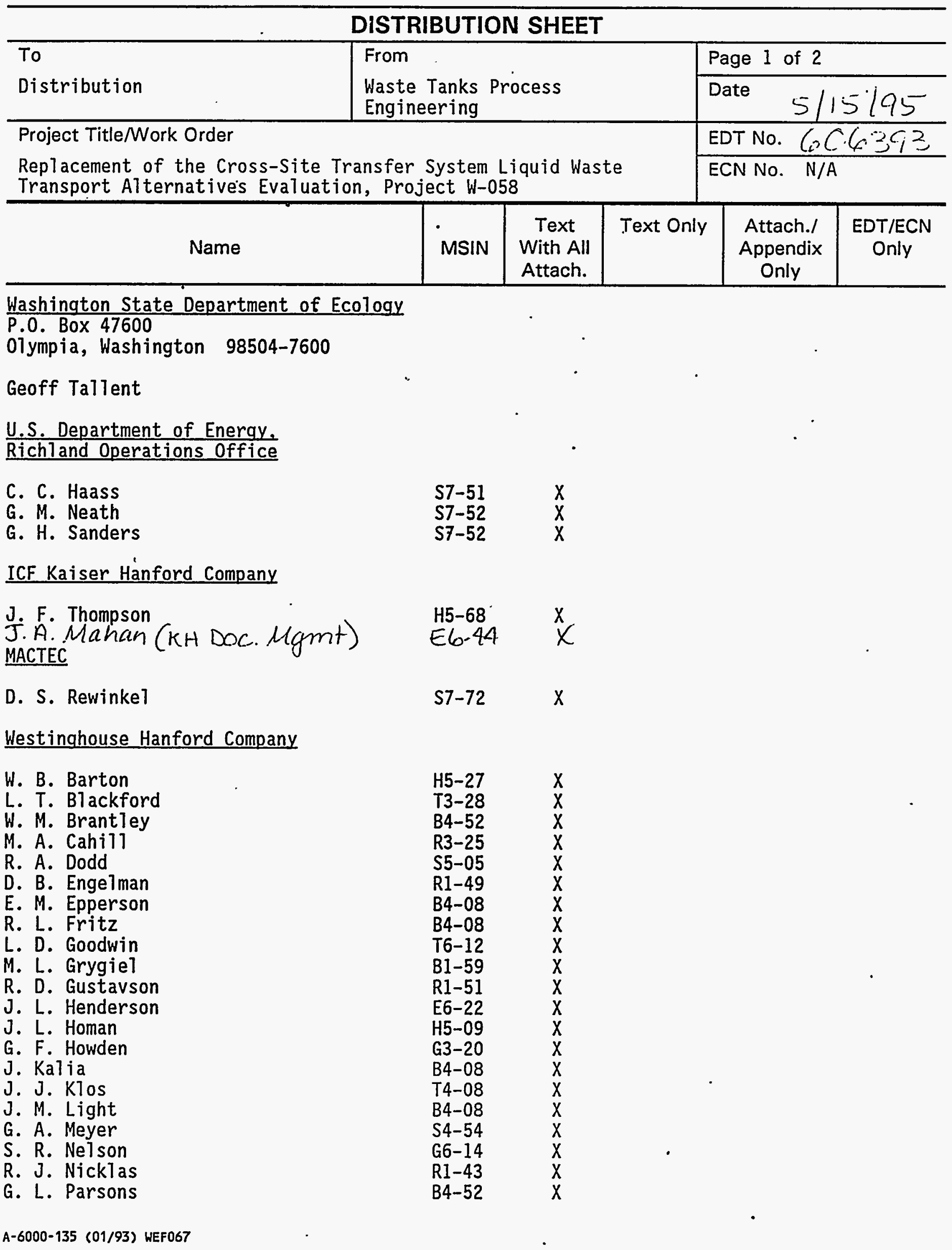


2. To: (Receiving Organization) Distribution
3. From: (Originating Organization) Waste Tanks Process Engineering

5. Proj./Prog./Dept./Div.: 6. Cog. Engr.:

D. V. Vo

8. Originator Remarks:

For approval. Comments have been incorporated. W-058 CSTS 71310/DECO4.

4. Related EDT NO.:

$N \mid 4$

7. Purchase Order No.: $N / A$

9. Equip./Component No.: $N / A$

10. System/Bldg./Facility: $N / A$

11. Receiver Remarks:

12. Major Assm. Dwg. No.: $N / A$

13. Permit/Permit Application No.: $N / A$

14. Required Response Date: 05/12/95

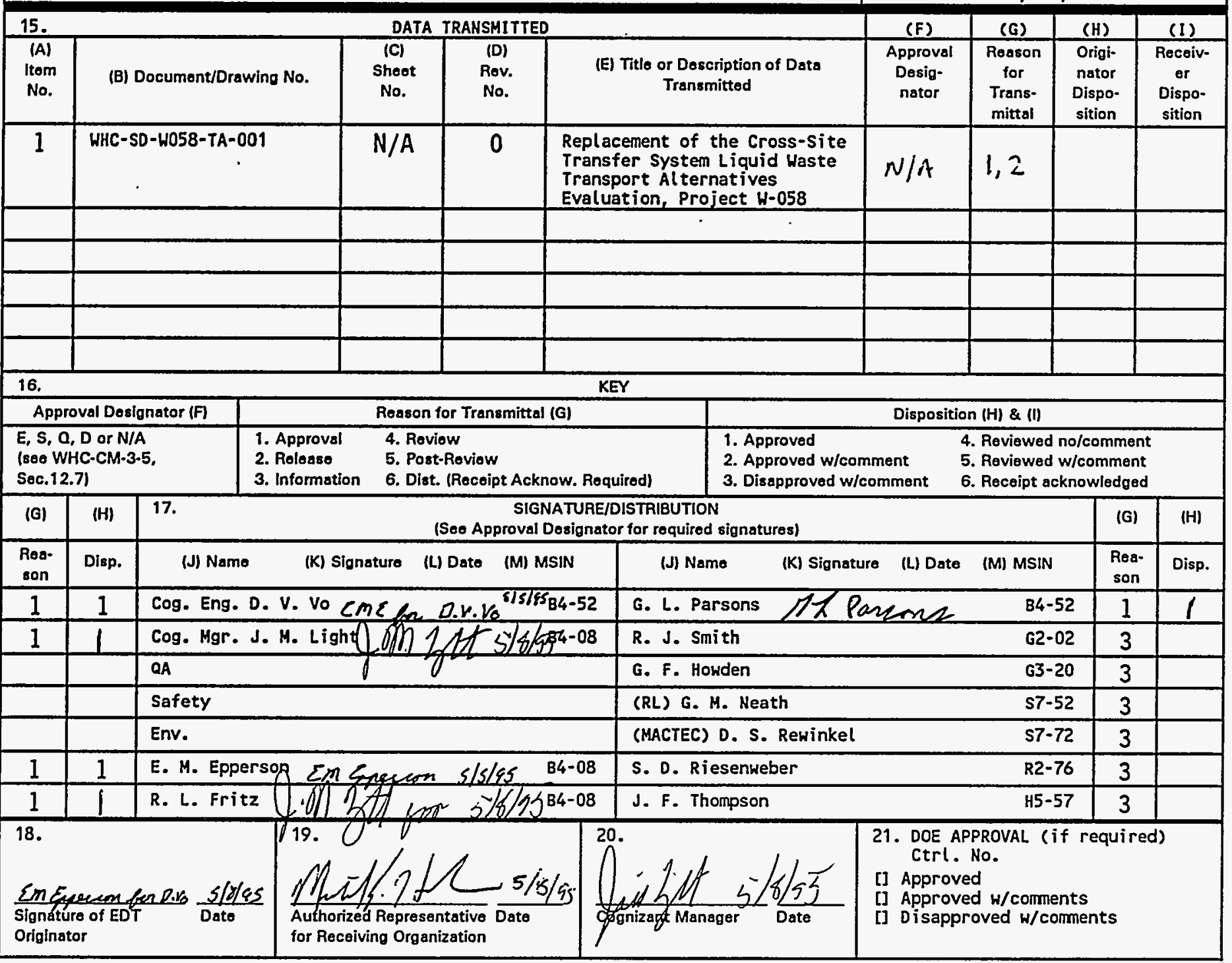

8D-7400-172-2 (04/94) GEF097 


\section{RELEASE AUTHORIZATION}

\begin{tabular}{|ll|}
\hline Document Number: & WHC-SD-W058-TA-001, Rev. 0 \\
\hline Document Title: & $\begin{array}{l}\text { Replacement of the Cross-Site Transfer System Liquid } \\
\text { Waste Transport Alternatives Evaluation, Project } \\
\text { W-058 }\end{array}$ \\
\hline Release Date: & - May 12,1995 \\
\hline
\end{tabular}

This document was reviewed following the procedures described in WHC-CM-3-4 and is: APPROVED FOR PUBLIC RELEASE

WHC Information Release Administration Specialist:

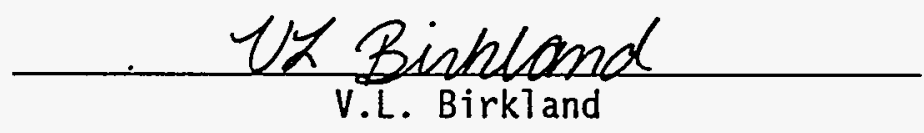

May 12, 1995

TRADEMARK DISCLAIMER. Reference herein to any specific commercial product, process, or service by trade name, trademark, manufacturer, or otherwise, does not necessarily constitute or imply its endorsement, recomendation, or favoring by the United States Government or any agency thereof or its contractors or subcontractors.

This report has been reproduced from the best available copy. Available in paper copy and microfiche. Printed in the United States of America. Available to the U.S. Department of Energy and its contractors from:

U.S. Department of Energy

office of Scientific and Technical Information (OSTI)

P.0. Box 62

Oak Ridge, IN 37831

Telephone: (615) 576-8401

Available to the public from:

U.S. Department of Cormerce

National Technical Information Service (NTIS)

5285 Port Royal Road

Springfield, VA 22161

Telephone: (703) 487-4650 
2. Title

Replacement of the Cross-Site Transfer System Liquid Waste Transport A7ternatives Evaluation, Project $W-058$

\section{Key Words}

Cross-site, cross-country, aboveground, underground, rail, French LR-56, trailer, tanker, cask, buried pipe, process pipe, slurry transport, transfer, liquid waste, tank waste, 204-AR, SY Tank Farm, high leve1, low level, CSTS, W-058, A. Tank Farm Complex

3. Number

WHC-SD-W058-TA-001 4. Rev No.

0

\section{Abstract}

This document examines high-/low-level radioactive liquid waste transport alternatives. Radioactive liquid waste will be transported from the 200 West Area to the 200 East Area and within the 200 East Areas for safe storage and disposal. The radioactive waste transport alternatives are the Aboveground Transport System (French LR-56 Cask System $[3,800 \mathrm{~L}\{1,000 \mathrm{gal}\}], 19,000-\mathrm{L}(5,000-\mathrm{gal})$ trailer tanker system, 75,700-L (20,000-gal) rail tanker system) and Underground Transport System (buried pipe [unlimited transfer volume capability]). The evaluation focused on the following areas: initial project cost, operational cost, secondary waste generation, radiation exposure, and final decommissioning. The evaluation was based on the near term (1995 to 2005) estimated volume of 49.509 million $L$

(13.063 million gal) and long term (1995 to 2028) estimated volume of 757.1 million $L$ (200 million gal). The conclusion showed that the buried pipe. (Underground Transport System) resulted in the lowest overall total cost for near and long term, the trailer container resulted in the highest total cost for near and long term, and the French truck was operationally impractical and cost prohibitive. 


\title{
REPLACEMENT OF THE CROSS-SITE TRANSFER SYSTEM LIQUID WASTE TRANSPORT ALTERNATIVE EVALUATION, PROJECT W-058
}

\author{
D. V. Vo \\ E. M. Epperson \\ May 1995 \\ Westinghouse Hanford Company \\ Richland, Washington
}

\section{DISCLAIMER}

This report was prepared as an account of work sponsored by an agency of the United States Government. Neither the United States Government nor any agency thereof, nor any of their employees, makes any warranty, express or implied, or assumes any legal liability or responsibility for the accuracy, completeness, or usefulness of any information, apparatus, product, or process disclosed, or represents that its use would not infringe privately owned rights. Reference herein to any specific commercial product, process, or service by trade name, trademark, manufacturer, or otherwise does not necessarily constitute or imply its endorsement, recommendation, or favoring by the United States Government or any agency thereof. The views and opinions of authors expressed herein do not necessarily state or reflect those of the United States Government or any agency thereof.

DISTRIBUTION OF THIS DOCUMENT IS UNLLMITED iWL 
WHC-SD-W058-TA-001

Revision 0

This page intentionally left blank.

$\div:=$ 
WHC-SD-W058-TA-001

Revision 0

\section{EXECUTIVE SUMMARY}

This report is an evaluation of high-/low-level radioactive liquid waste transport alternatives. The high-/low-level radioactive liquid waste will be transported from the 200 West Area to the 200 East Area and within the 200 East Areas for safe storage and disposal. This evaluation is required to document the results in response to a question raised during the comment period of the. Environmental Impact Statement for Safe Interim Storage of Hanford Tank Waste."

A previous study ${ }^{2}$ provided the foundation for this evaluation. The study investigated the technical feasibility and likelihood of approval for shipping large $(19,000 \mathrm{~L}[5,000 \mathrm{gal}])$ samples of actual tank waste from the 200. Areas to hot cell facilities in other areas on the Hanford Site. The study provided the estimated cost of the load/unloading facility and the risk assessment that were used in this evaluation.

The high-/low-level radioactive waste transport alternatives are the Aboveground Transport System (AGTS) and Underground Transport System (UGTS). The AGTS methods considered were an "off-the-shelf" shielded French LR-56 Cask System (3,800 L [1,000 gal]), a conceptual 19,000-L (5,000-gal) shielded trailer tanker system (truck), and a conceptual 37,850-L (10,000-gal) shielded rail tanker system. The UGTS method considered is a $60 \%$ design buried pipe system with untimited transfer volume çapability.

\footnotetext{
${ }^{1} \mathrm{DOE}, 1994$, Environmental Impact Statement for. Safe Interim Storage of Hanford Tank Waste, DOE/EIS-0212, Washington State Department of Ecology and U.S. Department of Energy, Richland Operations Office, 0lympia, Washington.

${ }^{2}$ Howden, G. F., 1993, Pilot Plant Hot Test Facility Siting Study, WHC-SD-WM-TA-143, Rev. 0, Westinghouse Hanford Company, Richland, Washington.
} 
The evaluation investigated the estimated high-/10w-level radioactive waste transport volume requirement for near term (1995 to 2005) of 49.509 million L (13.063 million gal) and long term (1995 to 2028) of 757.1 million L (200 million gal). The evaluation focused on the following areas: initial project cost, operational cost, secondary waste generation due to flushing, radiation exposure to personnel, and final decontamination and decommissioning (D\&D). The operational cost, secondary waste generation, radiation exposure, and $D \& D$ bases were developed to estimate a cost basis" for comparison with the initial project cost.

The detailed comparison of the three main candidate methods (buried pipe, trailer tanker car, and rail tanker car) are provided in Sections 2.0 and 3.0 of this report. The French LR-56 cask (truck) was not included in the detailed comparison because the large number of trips required made it impractical and uneconomical.

The buried pipe (UGTS) resulted in the lowest overall total cost for near term (1995 to 2005) and long term (1995 to 2028) as shown in Table 2-10. The higher initial project cost and final D\&D costs for the UGTS are offset by the lower operational, evaporation, and radiation exposure costs which result in a lowest overall total cost. The rail tanker car method (AGTS) appeared to have the next lowest overall total cost. However, the high radiation exposure to tank farm workers for routine operation is a concern for the 1ong-term, accident administrative control during transport of high-level liquid radioactive waste, and a fully loaded shielded $37,850-\mathrm{L}(10,000-\mathrm{ga} 7)$ rail tanker car nearly exceeding the railroad loading requirement. The trailer. tanker car (AGTS) resulted in the highest total cost for near term (1995 to 
2005) and long term (1995 to 2028) as shown in Table 2-10. Even without taking credit for radiation exposure cost, the UGTS buried pipe system for the total Hanford Site cleanup (1995 to 2028) total estimated cost is $65 \%$ less expensive than the lowest AGTS (rail tanker system). During the lowest demanded year (2003) for transport of liquid waste, rail tanker car and

- trailer tanker car roundtrips required travel distances exceeding the estimated yearly allowable AGTS mileage limit of $400 \mathrm{~km}$ (250 miles) for transport of high-level radioactive waste that was set as a limit for an incredible accident scenario without imposing administrative controls. Note that the AGTS mileage was based on the Howden document preliminary risk assessment. Therefore, actual mileage limits may be different than those presented here.

The buried pipe (UGTS) design is approximately $60 \%$ complete. The Preliminary Safety Analysis Report for Replacement of the Cross-Site Transfer System, Project $W-058$ revision ${ }^{1}$ and a system engineering design requirements document are being prepared. Also, the environmental documentation for the UGTS is we11 underway. . The integrated Project W-058 is supporting Tri-Party

: Agreement Operational Milestone M-43-07C of February 1998. Thus, there is no technical uncertainty associated with UGTS. In contrast, there are several uncertainties associated with the AGTS. The first one is related to the preparation of the project documents as required by DOE Order $4700.1 .^{2}$ These documents have not been prepared for the AGTS, which may impact the estimated

${ }^{1}$ Kidder, R. J., 1993, Preliminary Safety Analysis Report for Replacement of the Cross-Site Transfer System, Project W-058, WHC-SD-W058-PSAR-001, Rev. 0, Westinghouse Hanford Company, Richland, Washington.

${ }^{2}$ DOE, 1987, Project Management System, DOE Order 4700.1, U:S. Department of Energy, Washington, D.C. 
cost and/or schedule. The second uncertainty is the estimated project cost for AGTS, which was based on preconceptual ideas. The third uncertainty is related to meeting the Tri-Party Agreement Operational milestone by February 1998. This is the biggest uncertainty because the Conceptual Design, Title I (Preliminary Design), Title II (Definitive Design), and construction activities have not been started. The fourth uncertainty is related to - resolution of technical issues such as radiation exposure, additional accident administrative control during transport, a shielded 37,850-L (10,000-gal) rail tanker car exceeding the railroad loading requirements, remote operations (connect/disconnect), and seismically qualified equipment. 
1.0 INTRODUCTION . . . . . . . . . . . . . . . . . . . 1-1

1.1 SCOPE . . . . . . . . . . . . . . . . . . $1-1$

1.1.1 Waste, Volume, and Source ............. 1-1

1.1.2 Schedule .................. . . $1-1$

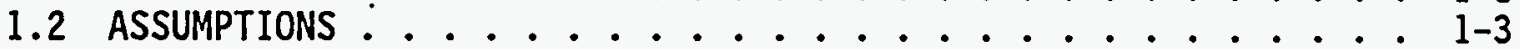

2.0 DISCUSSION . . . . . . . . . . . . . . . . . 2-1

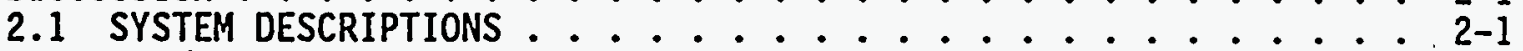

2.1.1 French LR-56 Cask ................ 2-1

2.1.2 Trailer Tanker Car - Truck ............ 2-4

2.1.3 Rail Tanker Car .............. 2-4

2.1.4 Buried Pipe .................. 2-4

2.2 COSTS AND COMPARISONS ................. . . . 2-13

2.2.1 Project Cost Comparisoṇ . . . . . . . . . . . 2-13

2.2.2 Operational Cost Comparison ........... . . 2-13

2.2.3 Evaporation Cost Comparison ............ 2-13

2.2.4 Personnel Exposure Cost Comparison . . . . . . . . 2-20

2.2.5 Decommissioning Cost Comparison ......... . 2-20

2.2.6 Summary Cost Comparison .................. . . 2-24

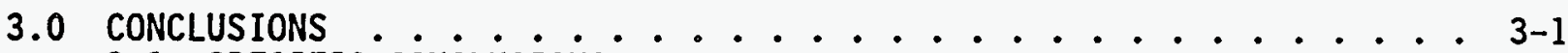

3.1 SPECIFIC CONCLUSIONS . . . . . . . . . . . . . 3-1

3.2 OVERALL CONCLUSIONS ................... $3-2$

4.0 TECHNICAL UNCERTAINTIES ................... . . 4-1

4.1 UGTS ........................... 4-...

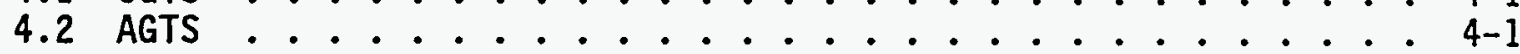

5.0 REFERENCES ......................... 5-1

\section{APPENDIXES}

A OPERATIONAL COST COMPARISON BASES . . . . . . . . . . . . . . A-1

B EVAPORATION COST COMPARISON BASES .................. B-1

C RADIATION EXPOSURE COST COMPARISON BASES . . . . . . . . . . . . c-1

D DECOMMISSIONING COST COMPARISON BASES . . . . . . . . . . . . D-1 
WHC-SD-W058-TA-001

Revision 0

\section{LIST OF FIGURES}

2-1 Proposed Aboveground Transportation System Transporter

Load/Unload Facility ................. 2-2

2-2 High-Level Liquid Waste Transporter ............. 2-3

2-3 Illustration of the 20,000-L Tank Mounted on a Heavy-Duty

Trailer........................ 2-5

2-4 Road Layout . . . . . . . . . . . . 2-6

2-5 Low-Leve1 Liquid Transporter . . . . . . . . . . . 2-7

2-6 Rail Layout . . . . . . . . . . . . . 2-8

2-7 Buried Pipe Route . . . . . . . . . . . . . . 2-9

2-8 Replacement of Cross-Site Transfer System . . . . . . . . 2-11

2-9 Underground Transportation System Diversion Box . . . . . . 2-12

2-10 Aboveground Transportation System--Radiological Surface Dose

versus Distance Away from the Cask ............ 2-23

\section{LIST OF TABLES}

1-1 Projected Volume and Source of Radioactive Liquid

Waste--1995 to $2005 \ldots . . \ldots$. . . . . . . . . . .

2-1 Number of Transfers/Trips--1995 to 2005 . . . . . . . . . 2-14

2-2 Capital Cost Comparison--1995 to 2005 . . . . . . . . 2-15

2-3 Operational Cost Comparison--1995 to 2005 . . . . . . . . 2-16

2-4 Operational Cost Comparison--1995 to 2028 . . . . . . . . 2-17

2-5 Evaporation Cost Comparison--1995 to 2005 . . . . . . . 2-18

2-6 Evaporation Cost Comparison--1995 to 2028 . . . . . . . . 2-19

2-7 Radiation Exposure Cost Comparison--1995 to 2005 . . . . . . 2-21

2-8 Radiation Exposure Cost Comparison--1995 to $2028 \ldots$. . . . . 2-22

2-9 Decommissioning Cost Comparison--1995 to 2005 . . . . . . 2-25

2-10 Summary Cost Comparison .............. 2-26 
WHC-SD-W058-TA-001

Revision 0

.REPLACEMENT OF THE CROSS-SITE TRANSFER SYSTEM

LIQUID WASTE TRANSPORT ALTERNATIVES

EVALUATION, PROJECT W-058

\subsection{INTRODUCTION}

\subsection{SCOPE}

This study was initiated in response to a question on the Environmental Impact Statement for Safe Interim Storage of Hanford Tank Waste (DOE 1994) (regarding the technical basis for preferring pipeline transport of Watch List waste to rail tanker car or trailer tanker car transport). This study includes information on volume projections, system descriptions, personnel exposure, technical uncertainties and costs associated with transportation of radioactive liquid waste from the 200 West Area to the 200 East Area and within the 200 East Area by the Aboveground Transport System (AGTS) versus the Underground Transport System (UGTS). The AGTS considered in this study was the French LR-56 cask, trailer tanker car, and rail tanker. car with the required load/unload facilities. The UGTS used in this study was buried pipes with associated diversion boxes that connect from the SY Tank Farm to the 244-A Lift Station.

\subsubsection{Waste, Volume, and Source}

A near-term (1995 to 2005) liquid waste transfer estimated volume (Toth 1995, Hanton 1994, Strode 1994) was developed and the details are shown in Table 1-1. During this period, the estimated total waste volume of 49.509 million L (13.063 million gal) is scheduled for transporting from the 200 West Area to the 200 East Area and within the 200 East Area. The total estimated volume includes mostly facility-generated waste, decommissioning cleanout, SY Tank Farm retrieval, and facility flushes. Table 1-1 identifies the facilities from which the waste originates and the quantity of waste associated with the respective facility.

A long-term (1995 to 2028) liquid waste transfer estimated volume of 757.1 million L (200 million gal) (Brantley 1994) was also considered in the evaluation. The long-term estimated volume includes the estimated near-term transfers, single-shell tank retrieval, and transfer from safe storage to disposal facilities.

\subsubsection{Schedule}

The schedule driver is the Hanford Federal Facility Agreement and Consent Order (Tri-Party Agreement) (Ecology et a1. 1994) Milestone M-43-07C, "Replacement of Cross-Site Transfer System Operational by February 1998." As described in WHC-SD-WM-EV-094, Tank Waste Remediation System Transfer Facility Compliance P7an (Hansen 1994), replacement of the existing cross-site transfer 


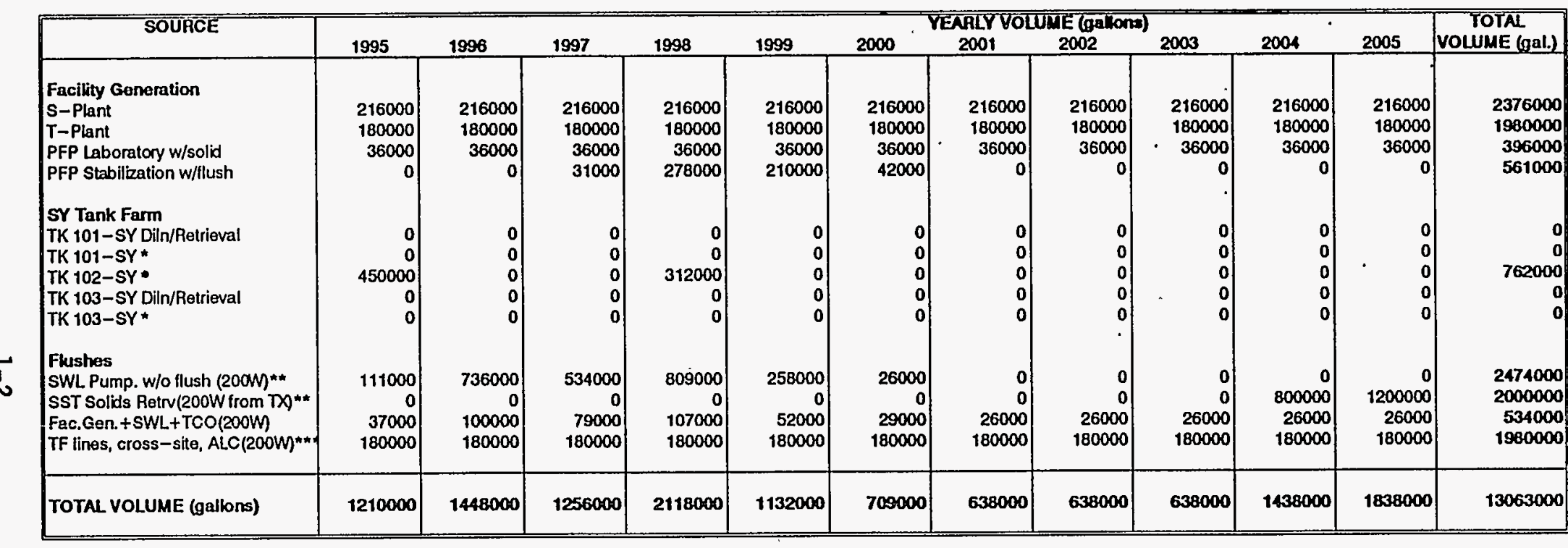

Unless otherwise flagged, data reported here is from the "Double Shell Tank Irwentory and Available Space" report, by A.D. Toth, 12/28/1994 -Waste Tank Summary Report for Month Ending, by B.M. Hanlon, WHC-EP-0182-81, 12/31/1994

*\#Operational Waste Volume Projection, by J.N. Strode, WHC-SD-WM-ER-029, Rev. 20, Table 3, 09/12/1994

wn+ Tank Farm lines, cross-site, Air Lift Circulator water flush/injection is equally divided between $200 \mathrm{~W}$ and $200 \mathrm{E}$

\section{TERMS/ACRONYMS}

ALC $=$ Air Litt Circulator
PFP $=$ Plutonium Finishing Plant
SST $=$ Single-Shell Tank

SWL = Salt - Wel Liquid
$\mathrm{TCO}=$ Terminal Ciean Out

TF = Tank Farm

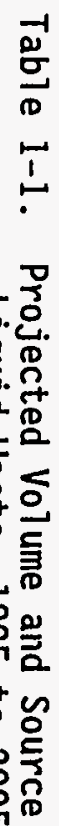

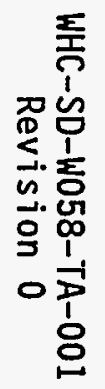


lines is required because the existing system does not comply with current environmental regulations and portions of the line are nearing the end of their design life.

\subsection{ASSUMPTIONS}

The following assumptions were made in preparing this study.

- Identical quantities of liquid waste are used for the AGTS and the UGTS.

- Personnel exposure was based on a surface dose of $200 \mathrm{mrem} / \mathrm{h}$ for the LR-56 Cask System (Smith 1994) and the same surface dose for rai1 tanker car and trailer tanker car systems. Personnel exposure was based on a surface dose of $<0.05 \mathrm{mrem} / \mathrm{h}$ for the outside of the UGTS diversion boxes (Brantley 1994).

- The AGTS options include an "off-the-shelf" 3,800-L (1,000-gal) shielded French truck, a conceptual 19,000-L (5,000-gai) shielded . trailer tanker car, and a conceptual 37,850-L (10,000-gal) shielded rail tanker car.

- The AGTS consists of two load/unload facilities located at the SY Tank Farm, and the A Tank Farm Complex.

- The UGTS consists of four diversion boxes located near the SY Tank . Farm, existing vent station, B Plant, and the A Tank Farm Complex.

- Decontamination and decommissioning (D\&D) of two of the load/unload facilities (AGTS) is equivalent to four of the diversion boxes (UGTS).

- The design and fabrication cost of the trailer tanker car and rail tanker car is the same as the French truck (LR-56), which is approximately $\$ 2.5$ million.

- Before release of the trailer tanker car or rail tanker car from the load/unload facility, radiological surveys to monitor for contamination and surface decontamination during upset conditions are required by HSRCM-1, Hanford Site Radiological Control Manual (WHC 1994). The radiological surveys and any surface decontamination will be contact handled. 
WHC-SD-W058-TA-001

Revision 0

This page intenționally left blank. 
WHC-SD-W058-TA-001
Revision 0

\subsection{DISCUSSION}

\subsection{SYSTEM DESCRIPTIONS}

Brief descriptions of the AGTS and the UGTS are given below. Additional details on each system may be found in the reference 1isted with each system. The modes of potential transport systems include the following:

- Shielded French LR-56 cask (modified off-the-shelf)

- Shielded trailer tanker car (conceptual)

- Shielded rail tanker car - truck (conceptual)

- Shielded buried pipe (60\% design).

Two load/unload facilities are required to support the AGTS. The conceptual design of the facility is shown in Figure 2-1. Because the AGTS is required to operate daily, the facility will be designed to minimize radiation exposure as required by DOE Order 6430.1A, General Design Criteria (DOE 1989). These facilities would be located at the SY Tank Farm. and at the 204-AR near. the A Tank Farm Complex. Additional details can be obtained from pages 5-21, 5-24, and 5-25 and Appendix B, Sections 3.1 and 3.2.2, of WHC-SD-WM-TA-143 (Howden 1993). Some major design features of the load/unload facilities include the following:

- Remotely connect and disconnect the pump, and maintain transfer pumps and valves using master/slave manipulators

- Drive-through load/unload shielded cells

- Remotely operated equipment (bridge-mounted electromechanical manipulator, crane) in load/unload cells for recovery from upset conditions

- Shielded doors at each end of load/unload cells and a second set of outer doors to provide a double air barrier in the event of a spill

- Zoning ventilation for trailer/rail cell, pump/valve cell, and solid waste handing cell to provide secondary confinement

- Sample storage capability $(94,600$ L [25,000 gal]).

The existing low-level waste unloading facility 204-AR will require modification to incorporate the above features for high-level waste activities.

\subsubsection{French LR-56 Cask}

The French truck is a $3,800-\mathrm{L}(1,000-\mathrm{gal})$ capacity, shielded $(5.1 \mathrm{~cm}$ [2 in.] of lead equivalent) container mounted on a trailer tanker car. The truck comes equipped with pumps, sampling devices, valves, etc. The truck is an "off-the-shelf" item and would require no design efforts (Figure 2-2), Detailed descriptions and cost can be obtained from WHC-SD-WM-TA-143, Pilot Plant Hot Test Facility Siting Report, Appendix M (Howden 1993). The French truck will use the existing road connected between the 200 West and 200 East Areas. 


\section{WHC-SD-W058-TA-001}

Revision 0

Figure 2-1. Proposed Aboveground Transportation System Transporter Load/Unload Facility.

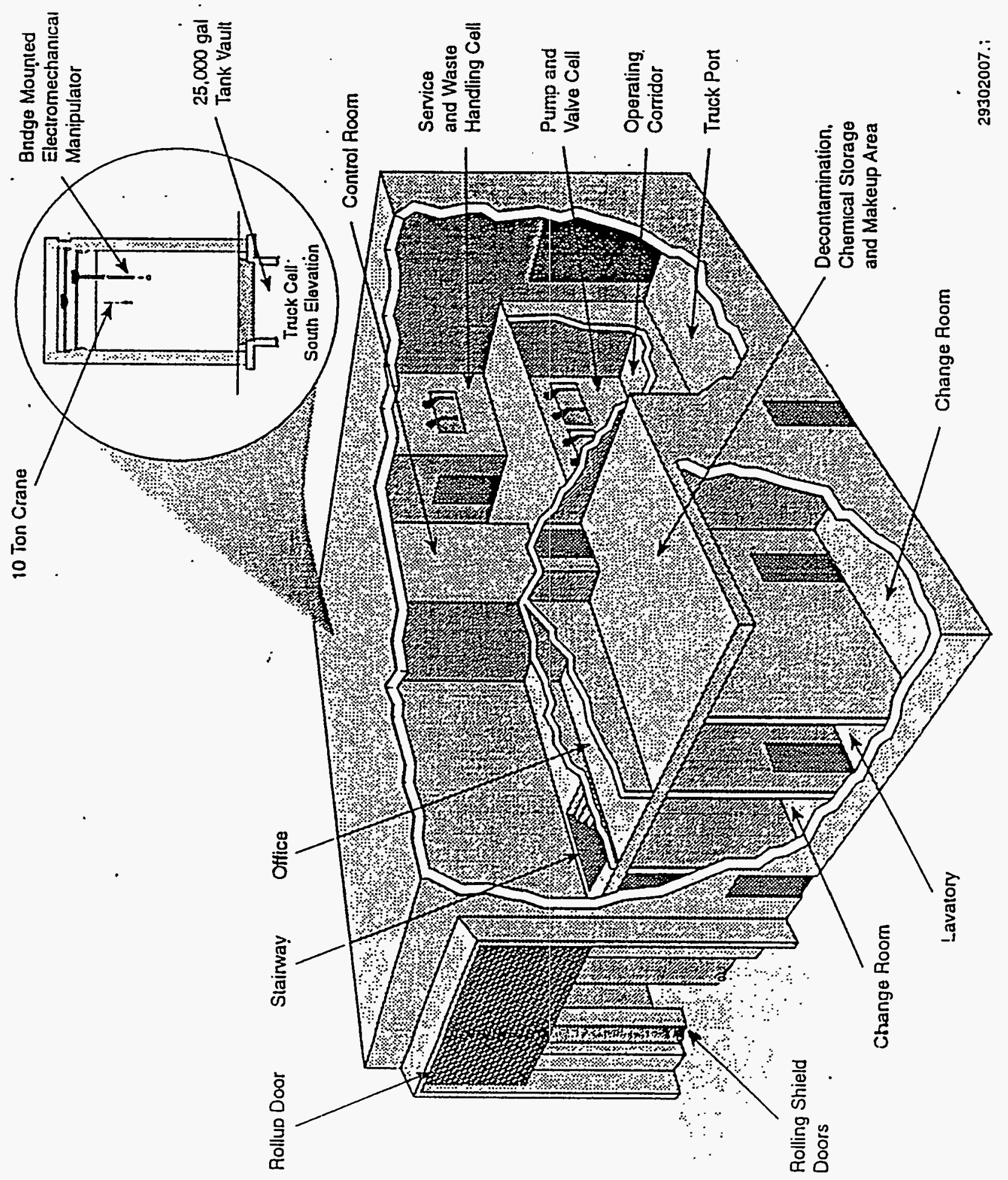







WHC-SD-W058-TA-001

Revision 0

\subsubsection{Trailer Tanker Car - Truck}

This is a 19,000-L (5,000-gal) capacity, shielded $(5.1 \mathrm{~cm}$ [2 in.] of lead) double-shell steel tank (about $2.4 \mathrm{~m}$ [ $8 \mathrm{ft}$ ] in diameter by $4.9 \mathrm{~m}$ [ $16 \mathrm{ft}$ ] long) mounted on a special low-boy heavy-duty trailer (Figure 2-3). Design and procurement activities would be required for this system. Detailed information can be obtained from WHC-SD-WM-TA-143, Appendix B, Section 3.2.3, pages B-14 through B-23 (Howden 1993). The trailer tanker car will use the existing road connected between the 200 lest and 200 East Areas with approximately $1.5 \mathrm{~km}(4,800 \mathrm{ft})$ of .potential additional new road in the. 200 East Area to avoid sharp road curves and proximity to existing office traiters (Trost 1995). The road distance from the SY Tank Farm facility to the A Tank Farm complex is $10.7 \mathrm{~km}$ ( 6.7 miles) and from the B Plant facility to the A Tank Farm complex is $1.9 \mathrm{~km}$ ( $1.2 \mathrm{miles})$. The actual road layout is shown in Figure 2-4.

\subsubsection{Rail Tanker Car}

The rail tanker car is a 37;850-L $(10,000-$ gal) capacity, shielded $(5.1 \mathrm{~cm}$ [2 in.] of lead equivalent) double-shell tank mounted on a special rail flat-car. This is a special shielded trailer tanker car and would require design modification and procurement activities. The non-shielded 75,700-L $(20,000-$ gal) rail tanker is shown in Figure 2-5. The rail tanker car will use the existing railroad connected between the 200 West Area and the 200 East Area with approximately $0.7 \mathrm{~km}(2,200 \mathrm{fi})$ of additional new railroad to provide rail spurs to the SY. Tank Farm, B Plant, and A Tank Farm Complex (Trost 1995). The rail distance from the SY Tank Farm facility to the A Tank Farm Complex is $15.5 \mathrm{~km}$ (9.7 miles), and $5.0 \mathrm{~km}$ ( $3.1 \mathrm{miles)}$ from the $B$ Plant facility to the A Tank Farm Complex. The actual rail layout is shown in Figure 2-6.

\subsubsection{Buried Pipe}

The UGTS pipe-in-pipe has two paralle] buried pipes connecting the SY Tank Farm at 241-SY-A and -B valve boxes in the 200 West Area with the 244-A Lift Station and 241-AR-151 diversion box in the 200 East Area. A third pipe connects B Plant with the cross-site transfer system in the 200 East Area. The route is approximately $10.4 \mathrm{~km}$ (6.5 miles) 1ong. The actual buried pipe route is shown in Figure 2-7. The system consists of $7.6-\mathrm{cm}\left(3-\mathrm{in}_{.}\right)$ diameter $304 \mathrm{~L}$ stainless steel pipes encased in 15.2-cm (6-in.) diameter carbon steel buried pipes with leak detection, three diversion boxes with booster pumps in two of the diversion boxes, and a vent station. The diversion boxes would be located near the SY Tank Farm, near B Plant, and at the A Tank Farm Complex, whereas the vent station is located at the highest point in the 600 Area. The replacement of the cross-site transfer system block diagram is shown in Figure 2-8 and additional details can be obtained from WHC-SD-W058-FDC-001, Functional Design Criteria for Project W-058, Replacement of Cross-Site Transfer System (Brantley 1994). The design of the facility is shown in Figure 2-9. Some major design features of the diversion boxes include the following: 


\section{WHC-SD-W058-TA-001}

'Figure 2-3. Illustration of the 20,000-L (5,000-Gal) Tank Mounted on a Heavy-Duty Trailer.

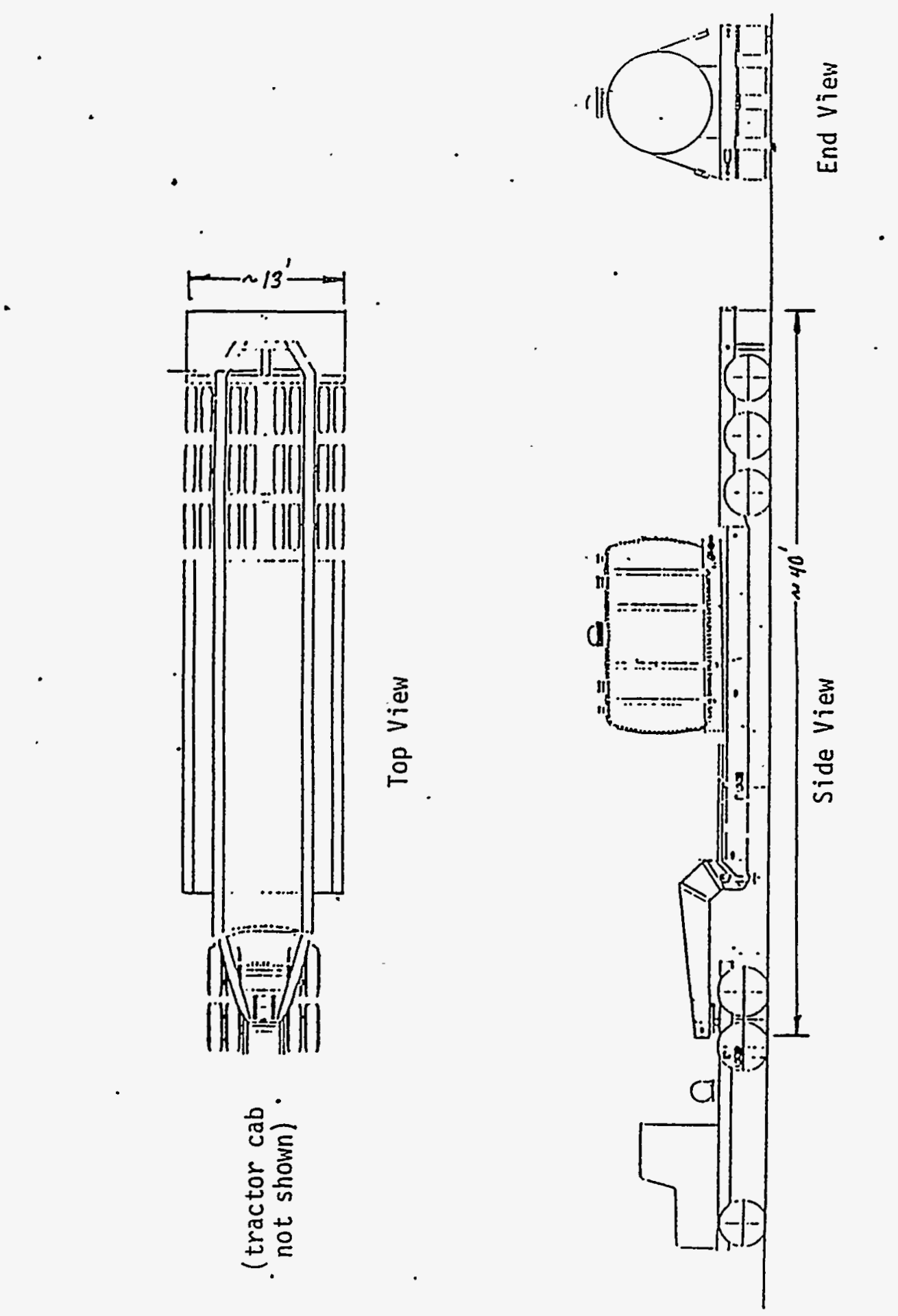


Figure 2-4. Road Layout.

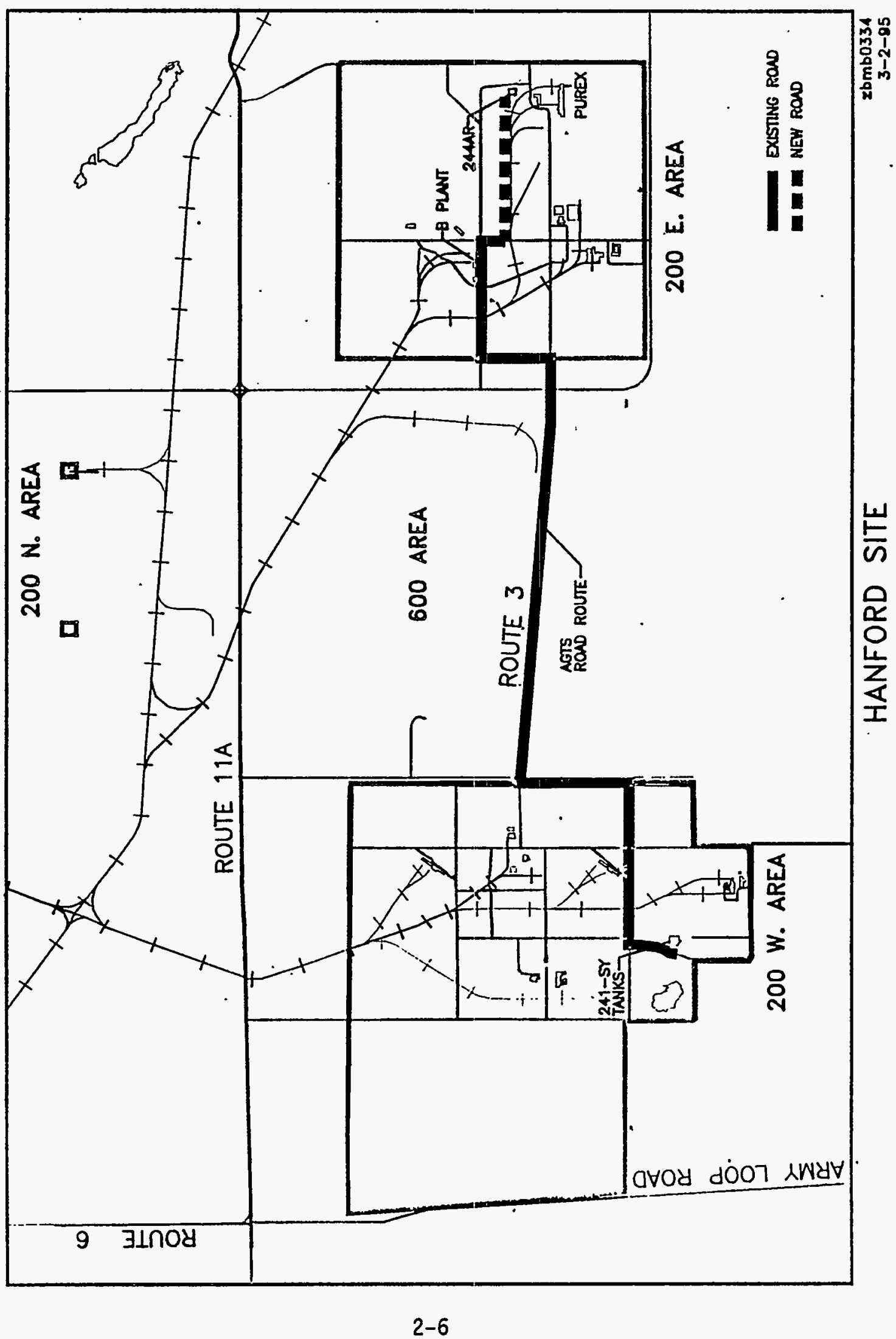


WHC-SD-W058-TA-001
Revision 0

Figure 2-5. Low-Level Liquid Transporter (Requires Shielding for High-Level).

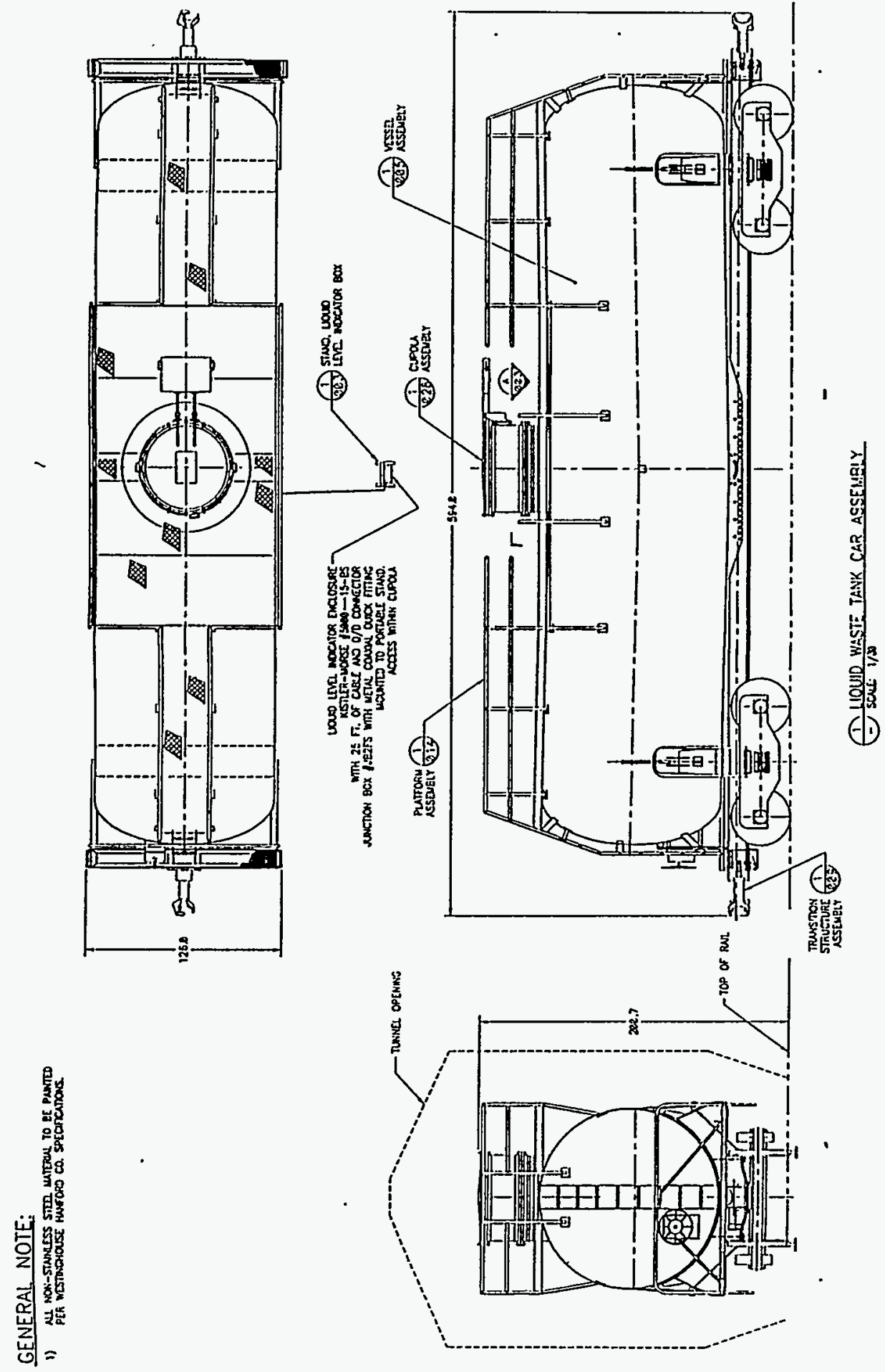


WHC-SD-W058-TA-001

Revision 0

Figure 2-6. Rail Layout.

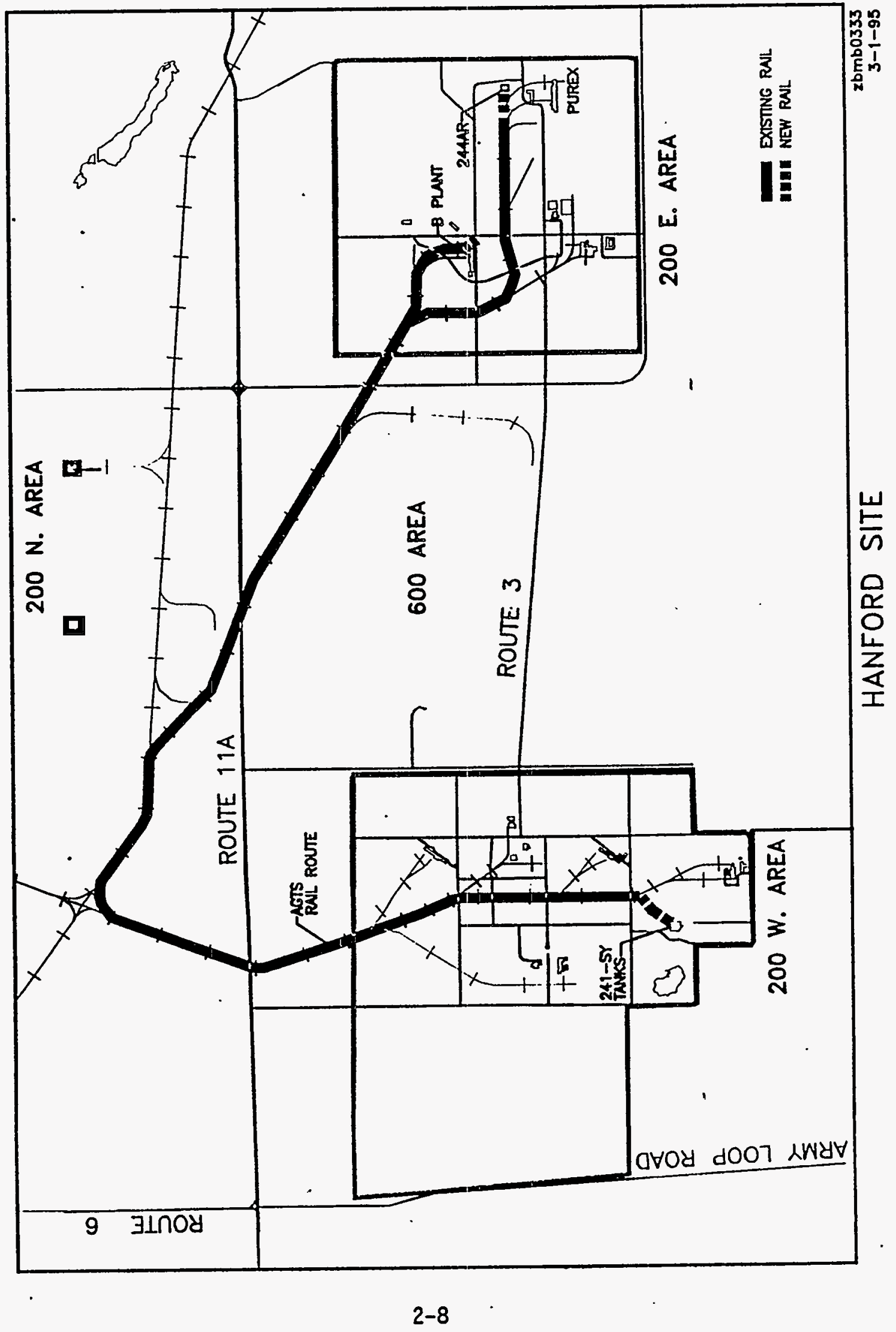




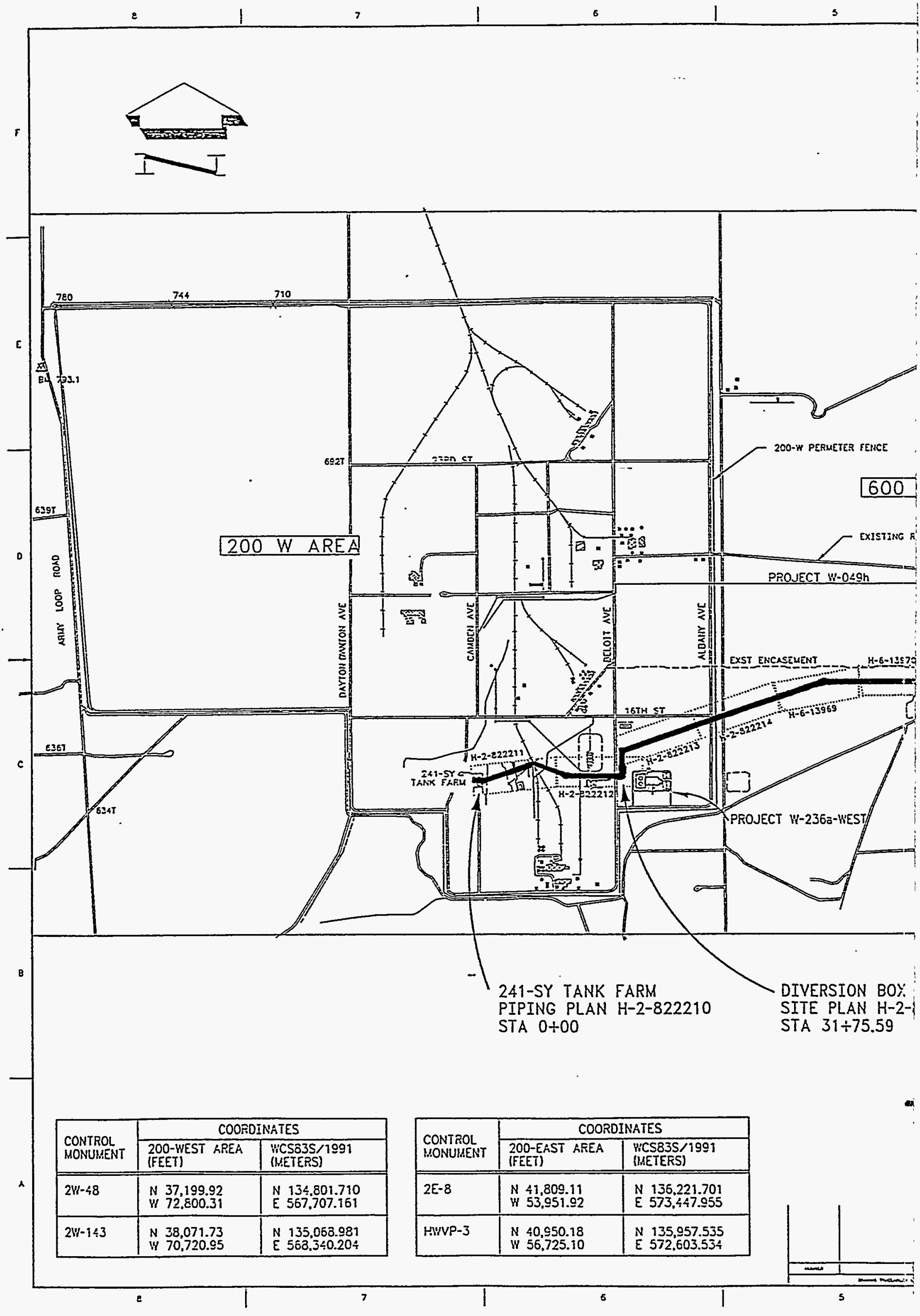


WHC-SD-W058-TA-COI

Revision 0

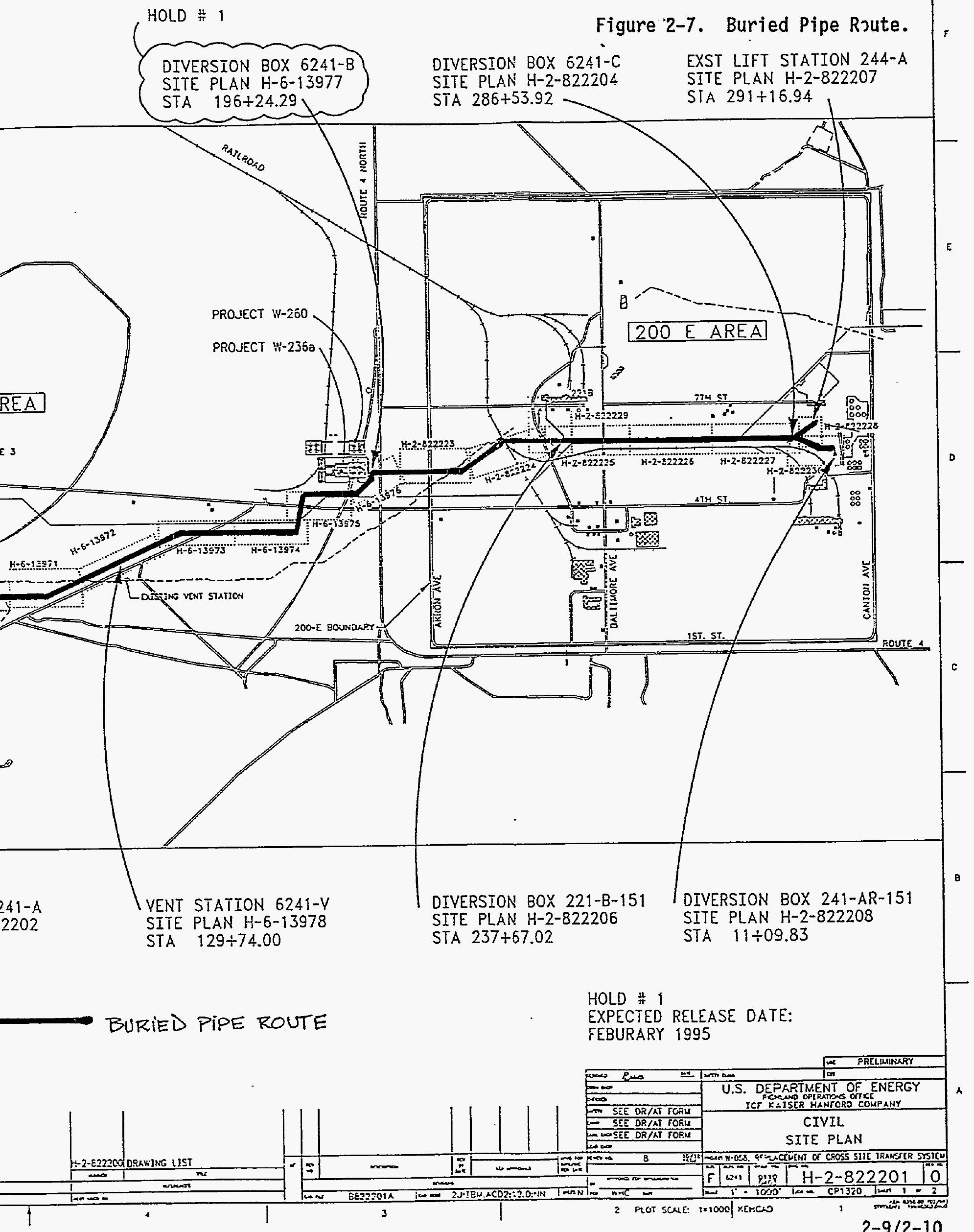




\section{WHC-SD-W058-TA-001 \\ Revision 0}

Figure 2-8. Replacement of Cross-Site Transfer System.

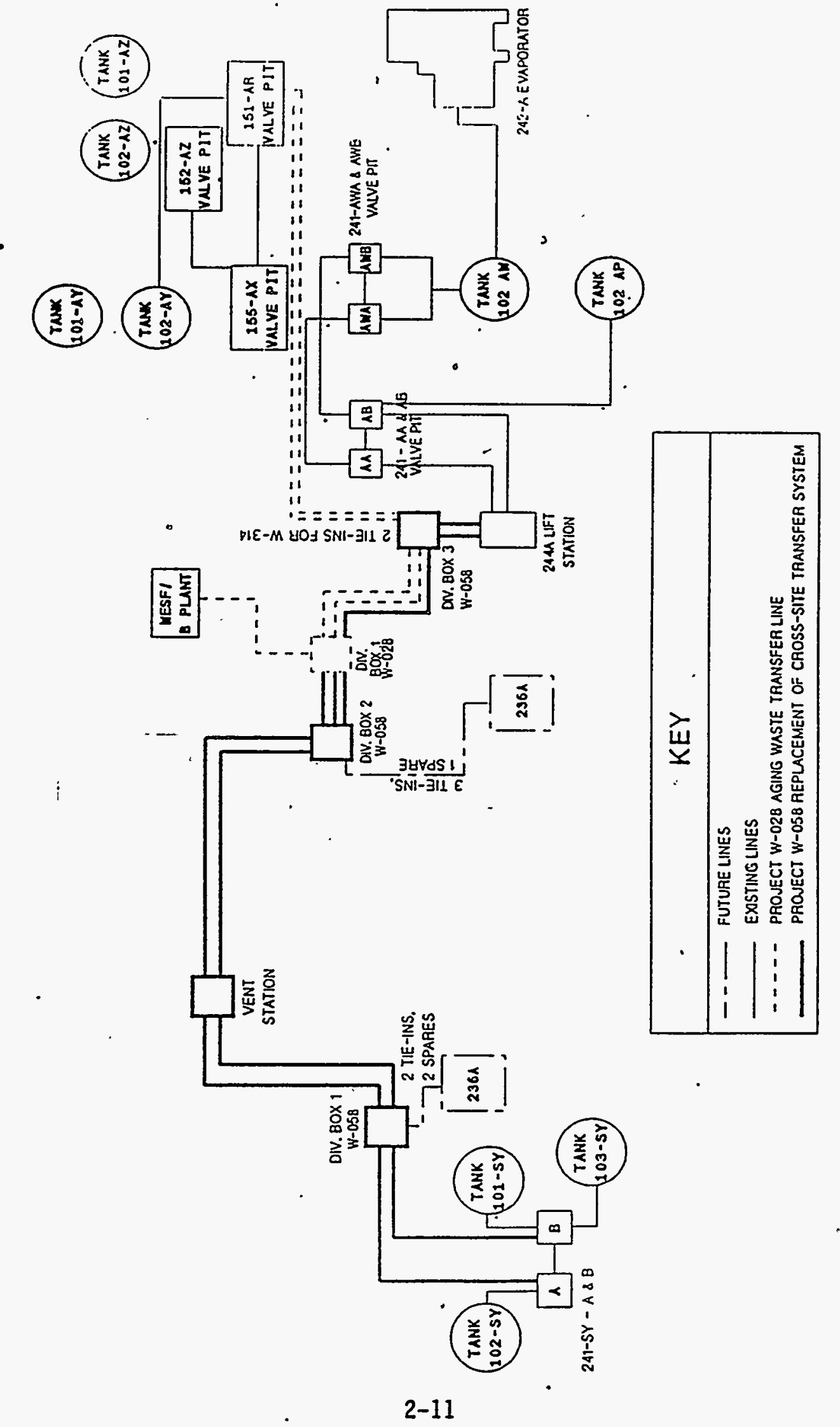




\section{WHC-SD-W058-TA-001 \\ Revision. 0}

Figure 2-9. Underground Transportation System Diversion Box.

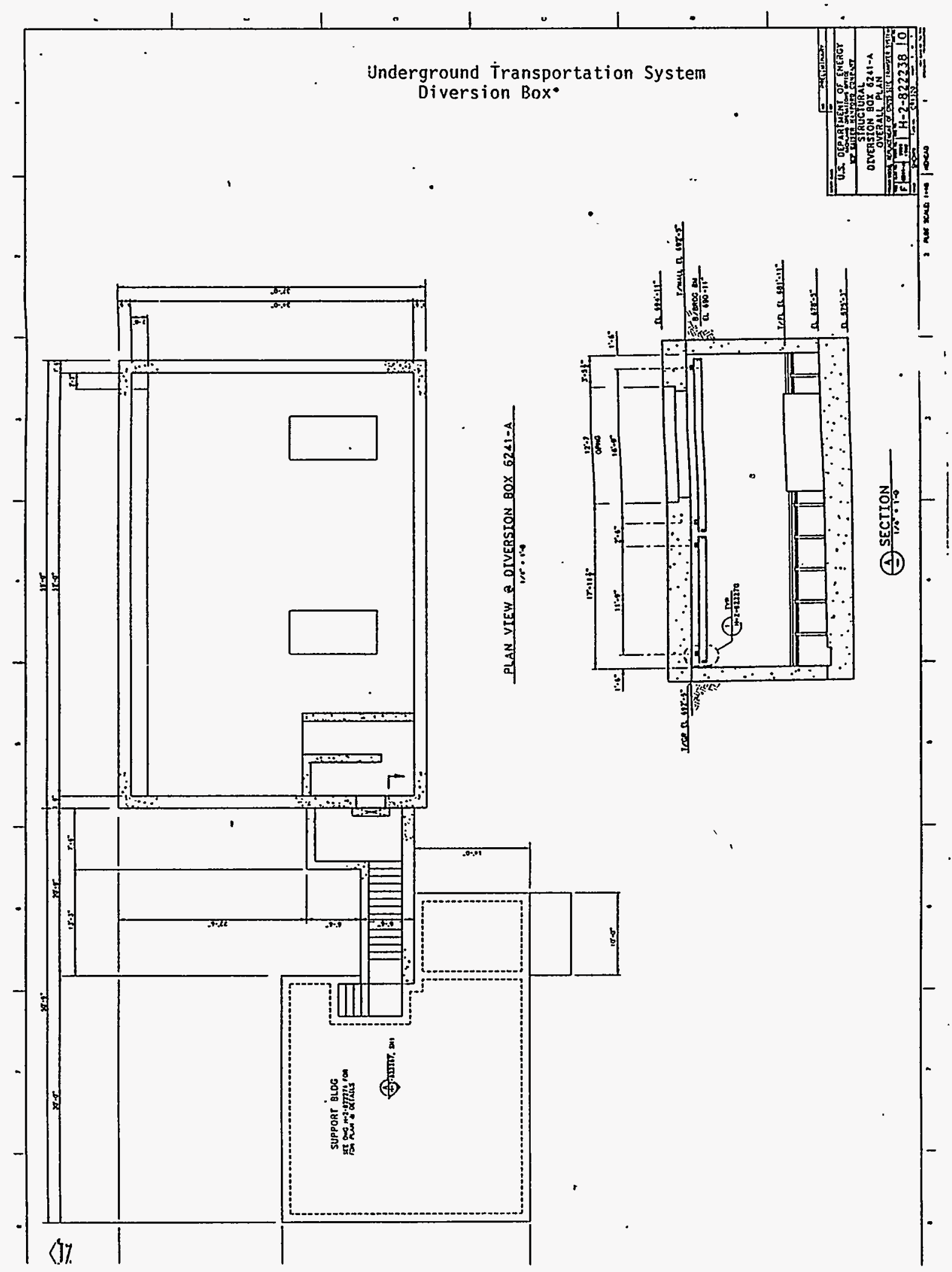


- Operation of the system is automated by using a monitor control system

- Shielded floor and flush capability for contact-handled "maintenance of transfer pumps, valves, and instruments

- Portable ventilation system for maintenance

- Permanent greenhouse and instrument building.

\subsection{COSTS AND COMPARISONS}

The data used to develop the various costs associated with each mode of waste transport are shown later in this section. The French truck was eliminated from further analysis because its 1 imited capacity resulted in an excessive number of trips (see Table 2-1) making it noncompetitive relative to the other modes of transport. The types of costs involved include the following:

- Project

- Operational

- Evaporation (disposal of flush water)

- Personnel exposure

- Decommissioning

- Summary.

\subsubsection{Project Cost Comparison}

The project cost for each transport mode is shown in Table 2-2. The project cost to go ranges from $\$ 49.2$ million for the UGTS, $\$ 31.9$ million for the rail tanker system, and $\$ 34.9$ million for the trailer tanker system. The UGTS costs include the pipeline, diversion boxes, vent station, pumps, and leak detectors. The AGTS costs include the vehicles, load/unload stations, portion of new road, and a rail spur.

\subsubsection{Operational Cost Comparison}

The expenses as the result of supporting personnel to transfer liquid waste (regardless of mode) are considered as operational costs. The support personnel are typically operations, engineering, health physics, maintenance, quality assurance, safety, and others.

As shown in Tables 2-3 and 2-4, the cost of transporting radioactive liquid waste via the UGTS is $\$ 0.17 / L$ ( $\$ 0.63 / \mathrm{gal})$. This compares favorably to the least expensive AGTS mode (rail tanker) of $\$ 0.30 / \mathrm{L}(\$ 1.15 / \mathrm{gal})$.

\subsubsection{Evaporation Cost Comparison}

After each transfer of radioactive Tiquid waste the transferring vehicle (regardless of mode) will require flushing. Tables 2-5 and 2-6 show the 
WHC-SD-W058-TA-001

Revision 0

Table 2-1. Number of Transfers/Trips--1995 to 2005.

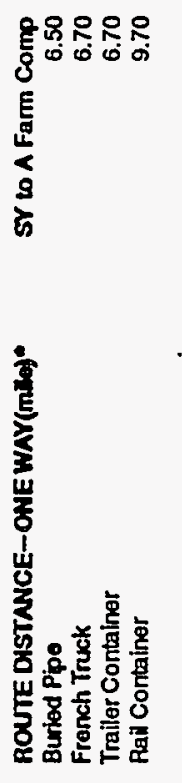

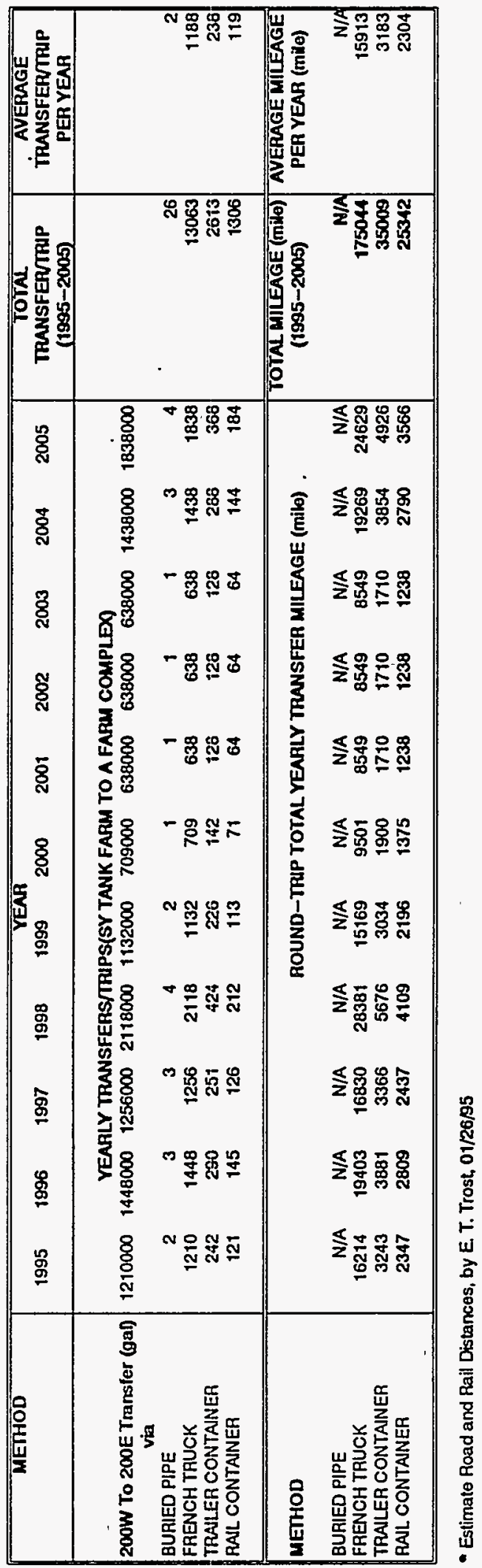


Pipe/Route Longth Addition (mite) Buried Pipe:

Truck:

Rail:

6.5 (SY Tank Farm To 244-A-Lit Station)

0.92 (Use 200 Area Exising Rosd)

Bruck:*

0.42 (Rail Spurs to SY and A TF Complex)

Rail:"

Minimum Required Now Facility

Buriad Pipe (Diversion Box):

Truck (Load/Unload)

Rail(Load/Unload):

\section{Facility Cost (\$/Facility)}

4 (DB*1, Vent Station, MWTF-Eas, DB*3) Buried Pipe (Diversion Box):

1 (SY Tank Farm) Truck (LoadNnload):

Rail(Load/Unload):"*

Upgrade Existing

Por Length (\$/mile)
Upgrade Existing
N/A
9000000
9000000

\section{Minimum Modified Facility \\ Buried Pipo (Diversion Box):}

Truck (Load/Unload)

1 (SY Tank Farm)

9000000

$1(204-A R)$

$\stackrel{n}{1}$

Rail(Load/Unload):

Pipe/Required Transportation Vehiclo

Buried Pipe (Pumps, Leak Det, etc.):

Truck:

Pipe/Transportation Vehicle Cost (\$/each)

1 (inelude spare capability) Buried Pipe (Pump, Leak Det. etc.)

Truck: ${ }^{+\infty+\hbar}$

3 (1 spare)
2 (1 spare)

Rail:**t:

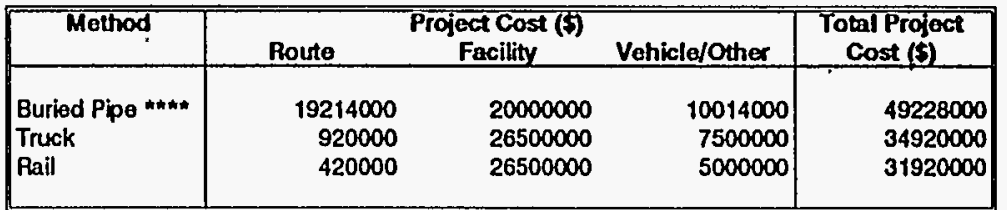

(Excalated 1995)

(Exalated 1993)

(Escalxed 1993)

1478000

1000000

1000000

\section{Now Facility}

5000000

17500000

17500000

10014000
2500000
2500000

2500000

- Estimate Road and Rail Construction, by E T. Trost, 01/26/95

** Pilot Plant Hot Test Facility Siting Study, by G. F. Howden, WHC-SD-WM-TA-143 Rev. 0, Table 5-2, 11/18/1993

**\# W. A Brooks provides the French truck transporter LR-56 (1000 gallons capacity) estimated cost, 02/14/95

wh**: Total Estimated W-058 Project Costs is $\$ 52700000$. However, the Prolect had spent $\$ 3472000$ 
WHC-SD-W058-TA-001

Revision 0

Table 2-3. Operational Cost Comparison--1995 to 2005.

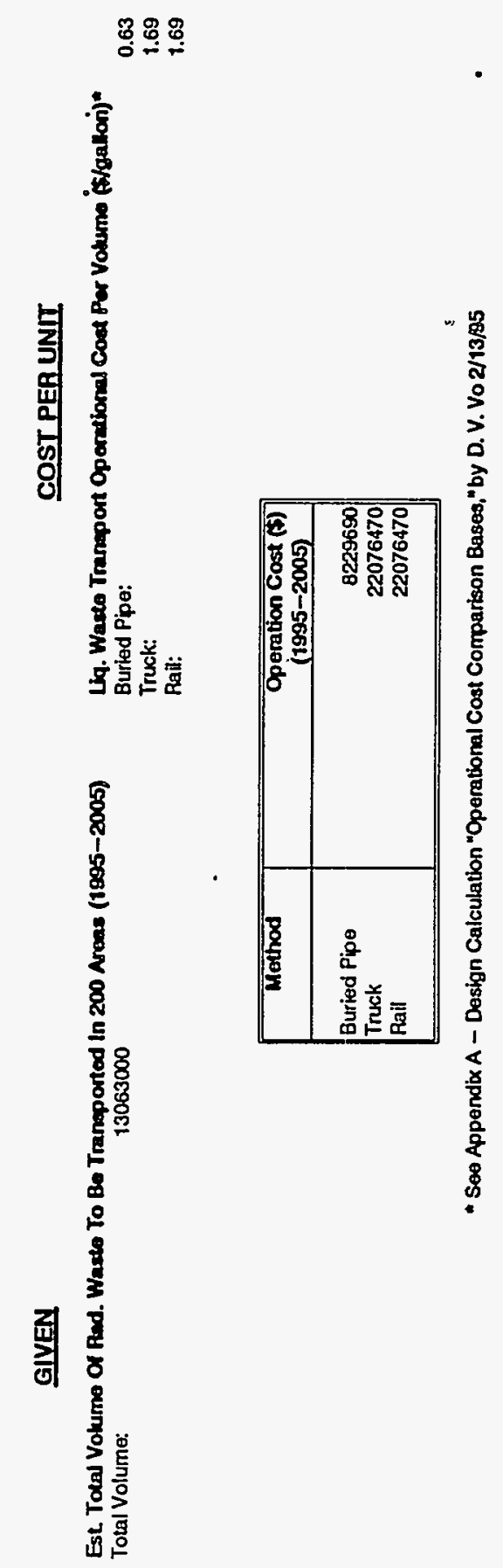


WHC-SD-W058-TA-001

Revision 0

Table 2-4. Operational Cost Comparison--1995 to 2028.

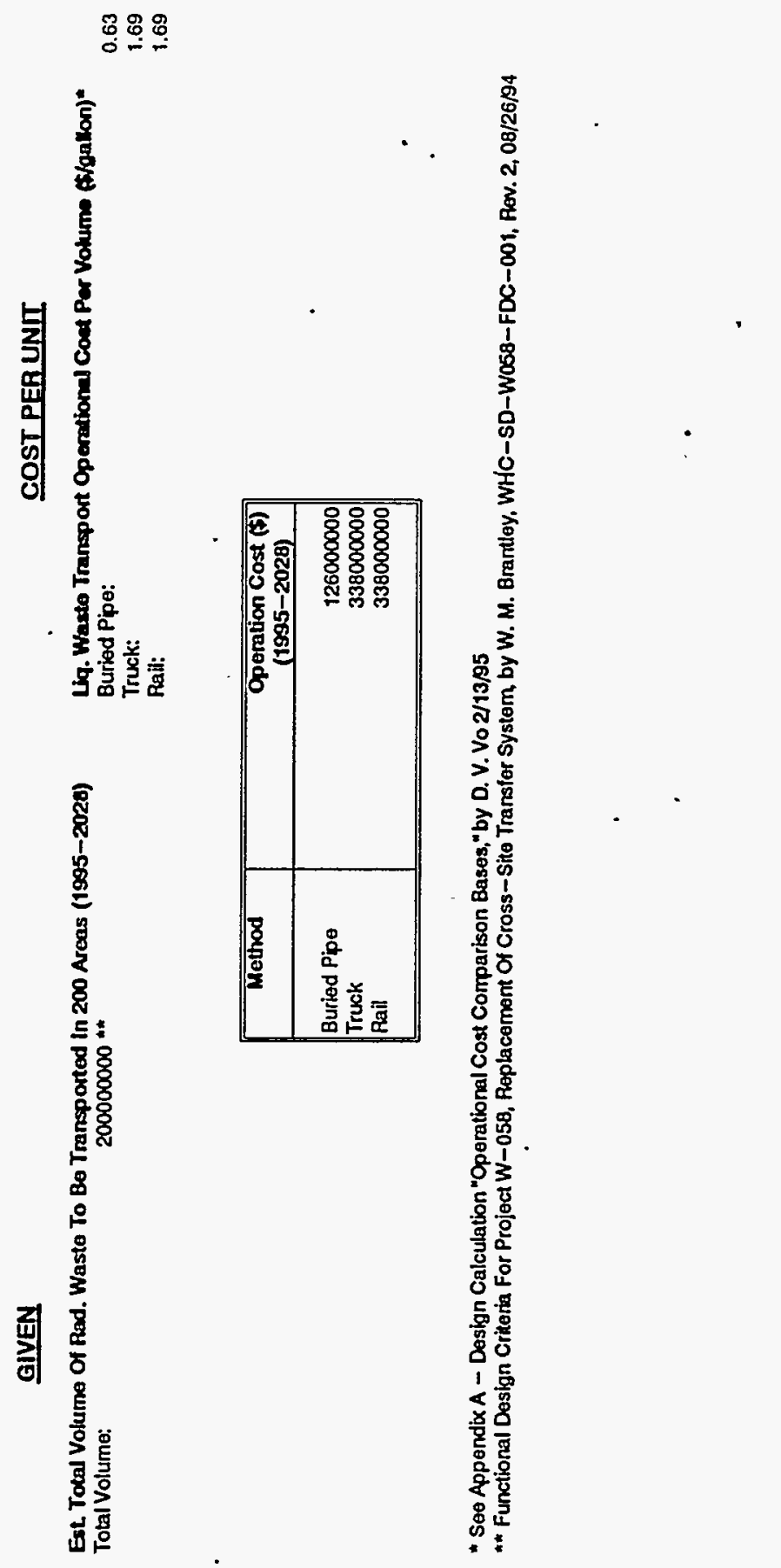


GIVEN

Total Number of Trips or Transfers (Tablo 2) Buriod Pipo:

Truck:

Rait:

Flush Water Volume (gallon)/Transfer*

Buried Pipe:

Truck:

Rail:

$\stackrel{N}{1}$
COST PER UNIT

Wasto Wator Evaporation Cost (F/galion) ${ }^{\circ}$

Buried Plpe:

Truck:

Rail:

Fush Water Evaporation Cost (\$/transfor)

Buriod Pipe (1 Volume Fill and 1 Volume Flush):

Truck (I Volume Flush):

Rail (1 Voluma Flush):
20 (SY LA Axm Complex)

1306 (SY to A Farm Complex)

32000
4300

4900

\section{5}

2.52

2.52

80640

12348

\begin{tabular}{|l|r|}
\hline \multicolumn{1}{|c|}{ Method } & $\begin{array}{c}\text { Evaporation Cost (\$) } \\
\text { (fiush water) }\end{array}$ \\
\hline Buried Pipe & 2106801 \\
Truck & 28310134 \\
Rail & 16130192 \\
\hline
\end{tabular}

- Soe Appendix B - Design Calculation "Evaporation Cost Comparison Bases," by D. V. Vo 2/10/85 


\section{GIVEN}

Total Number of Trips or Tranefere

Buried Ppo:

Truck:

400 (SY to A Firm Compla)

40000 (SY to A Farm Complex)

20000 (SY to A Farm Complex)

Flusti Water Volume (gallon)/Transfer*

Buried Pipo:

Truck:

32000

32000
4300

4300

$\stackrel{N}{\stackrel{1}{0}}$

Rail:

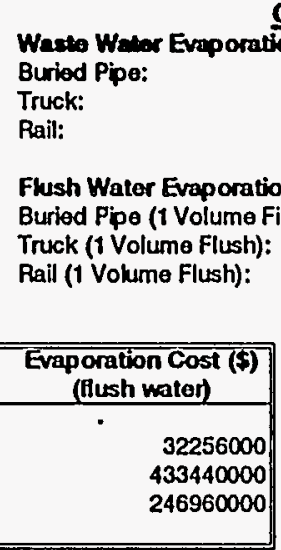

- See Appendlx B - Design Calculation "Evaporation Cost Comparison Bases," by D. V. Vo 2/10/95

80640
10836

12348

\begin{tabular}{|l|c|}
\hline \multicolumn{1}{|c|}{ Method } & $\begin{array}{c}\text { Evaporation Cost (\$) } \\
\text { (fiush water) }\end{array}$ \\
\hline Buried Pipo & $\cdot$ \\
Truck & 32256000 \\
Rail & $\mathbf{4 3 3 4 4 0 0 0 0}$ \\
\hline
\end{tabular}


quantity of flush water required for each mode of transport and the cost to dispose of (evaporate) the flush water. The unit cost of evaporation is the same regardless of the transport mode. The total cost for evaporation is less for the UGTS because less flush water is required in transporting 49.509 million L (13.063 million gal) of waste vi.a UGTS than AGTS.

\subsubsection{Personne1 Exposure Cost Comparison}

The detriment associated with radiation exposure to personnel is expressed in dollar value. The cost related to radiation exposure due to radiological survey is shown in Tables 2-7 and 2-8. The tables show that the buried pipe mode of waste transport is more cost efficient than the AGTS, because the UGTS is operated remotely via a monitor control system and it has been designed to have a very small radiation surface dose. Dollar costs are the principal factor, although the acceptability of a policy of "-burning out" workers is debatable and is an issue under as low as reasonably achievable (ALARA) principies. If those costs are not included, the rail mode has a small economic advantage during the 1995 to 2005 time frame. However, when the time frame is extended to 2028 the UGTS has a large dollar advantage over the AGTS with or without the personnel replacement costs.

The UGTS and the AGTS will address ALARA considerations to minimize personnel radiation exposure. The UGTS will be designed to have a maximum surface dosage of $0.05 \mathrm{mrem} / \mathrm{h}$ and the AGTS will have sufficient shielding to 1 imit surface dosage to $200 \mathrm{mrem} / \mathrm{h}$. For the AGTS, a radiological smear survey is required to be performed on the cupola (inside), cupola (outside), platform (deck), underplatform, walk platform, handrails, ladder, tanker sides, tanker ends, belly/drain, coupling/knuckle, assembly and lever, hand braker, wheel truck assemblies, and wheels. Because several of the survey areas do not directly contact the tanker car surface, a radiation exposure dose versus distance calculation was done (Figure 2-10). Therefore, the selected average radiation exposure dose of $100 \mathrm{mrem} / \mathrm{h}$ at approximately $75 \mathrm{~cm}(2.5 \mathrm{ft})$ from the cask is used in this evaluation. Westinghouse Hanford Company guidelines assign a cost of $\$ 2,500 /$ man-rem for health effects and $\$ 22,500 /$ man-rem for replacement personnel (the cost of replacing the individual worker in the specific work force who has approached a preset 1imit). The replacement personnel cost is based on the average weekly wages and benefits and assumes 12 person-weeks to train each affected worker. These numbers were used in computing the costs for personnel exposure. Thus, the personnel health $(\$ 2,500 /$ man-rem) associated cost is designated as the lower cost and the replacement personnel $(\$ 22,500 /$ man-rem) associated cost is designated as the upper cost in the evaluation. However, it is assumed that the upper cost can be reduced to $\$ 11,250 /$ man-rem by proper planning and managing of proposed personnel.

\subsubsection{Decommissioning Cost Comparison}

Regardless of the transport mode employed, decommissioning will be required. Decommissioning costs for each mode of transport are shown in Table 2-9. The costs for decommissioning of the buried pipe (UGTS) are about $\$ 17.7$ million compared to $\$ 1.3$ million and $\$ 2.1$ million for trailer tanker 


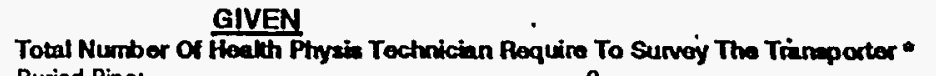
Buried Pipe:

Truck:

Rail:

Estimated Radiological Survey Time (hour)/Person* Buriod Pipo: Truek:

$$
\begin{aligned}
& 8 \\
& 8 \text { (survey before leaving and } \\
& 8 \text { (survey before leaving and } \\
& 26 \text { (SY to A Farm Complex) } \\
& 2613 \text { (SY } 10 \text { A Farm Complex) }
\end{aligned}
$$$$
\text { Rail: }
$$

Burled Pipe:

8 (survey beloce leaving and beforeunbading) Truck:

\section{COST' PER UNIT Buriod Pipo: \\ Truck: \\ Perion-Fonis L \\ Rail: \\ Radiation Surface Dose (mfem/hx)}

$2500 \quad 11250$

22500011250

Buried P

Total Number Of Trips or Transfers (Table 2)

Buried Pipe:

Truck:

\begin{tabular}{|c|c|c|c|}
\hline \multirow[t]{2}{*}{ Method } & \multicolumn{3}{|c|}{ Radiation Exposure Cost (S) } \\
\hline & Lower & Upper & Upper \\
\hline $\begin{array}{l}\text { Buriod Pipe } \\
\text { Truck } \\
\text { Rail }\end{array}$ & $\begin{array}{r}0 \\
10450400 \\
5225200\end{array}$ & $\begin{array}{r}0 \\
94053600 \\
47026800\end{array}$ & $\begin{array}{r}0 \\
47026800 \\
23513400\end{array}$ \\
\hline
\end{tabular}

1306 (SY 10 A Fam Comples)

Note: Survey time does not inlude the remaining 8 hours when the transporter is not full (i.e. after unloading and before loading of liquid waste)

- Seo Appendix C - Design Calculation "Radiation Exposure Cost Comparison Bases," by D. V. Vo 2/10/95

** Cost Benefit Analysis at Westinghouse Hanford Company, by R. L Brown and C. J. Stephán, WHC-SA-1533-FP, April 1992. 
GIVEN

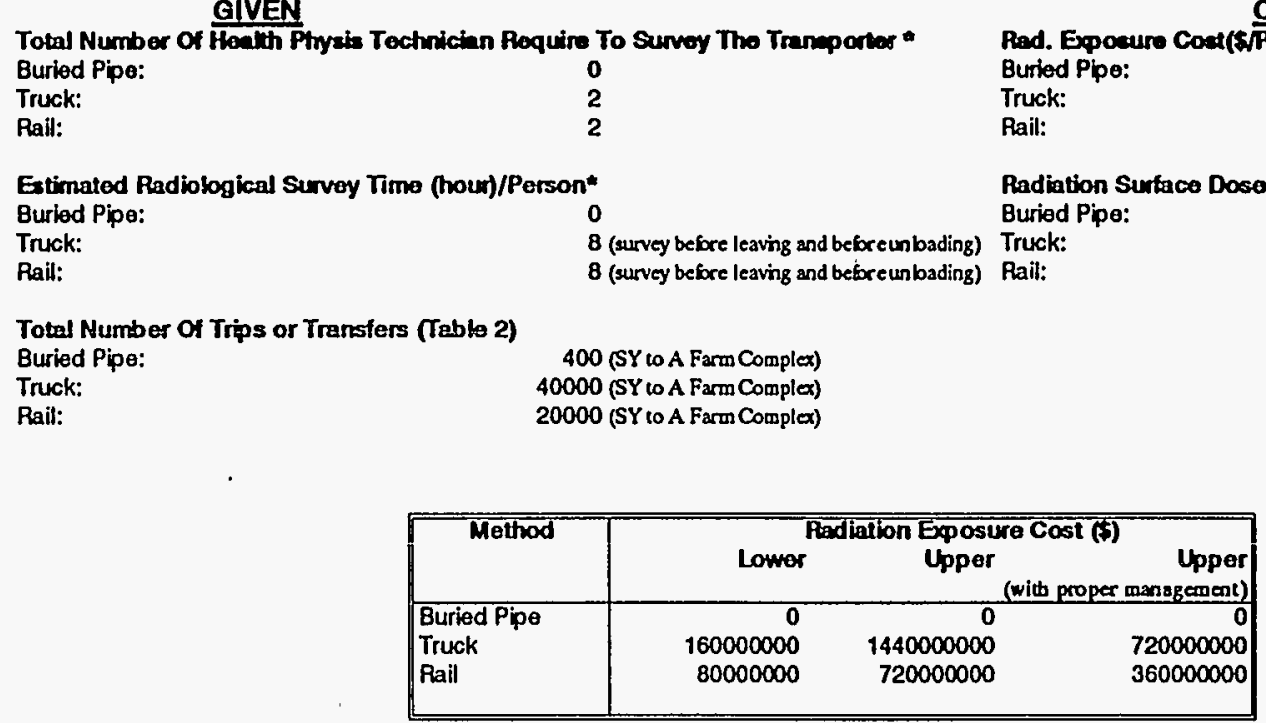

$N$
$N$

Note: Survey time does not inlude the remaining 8 hours when the transporter is not full (i.e. after unloading and before loading of liquid waste)

- See Appendix C - Design Calculation "Radiation Exposure Cost Comparison Bases,"by D. V. Vo 2/10/95

** Cost Benefit Analysis at Westing house Hanford Company, by R. L Brown and C. J. Stephan, WHC-SA-1533-FP. April 1992.

\section{COST PER UNIT}

2500

2500
2500
2500

$22500 \quad$ Upper

$22500 \quad 11250$

$22500 \quad 11250$

0.05
100

100
100 
WHC-SD-W058-TA-001

Revision 0

Figure 2-10. Aboveground Transportation System--Radioiogical Surface Dose versus Distance Away from the Cask.

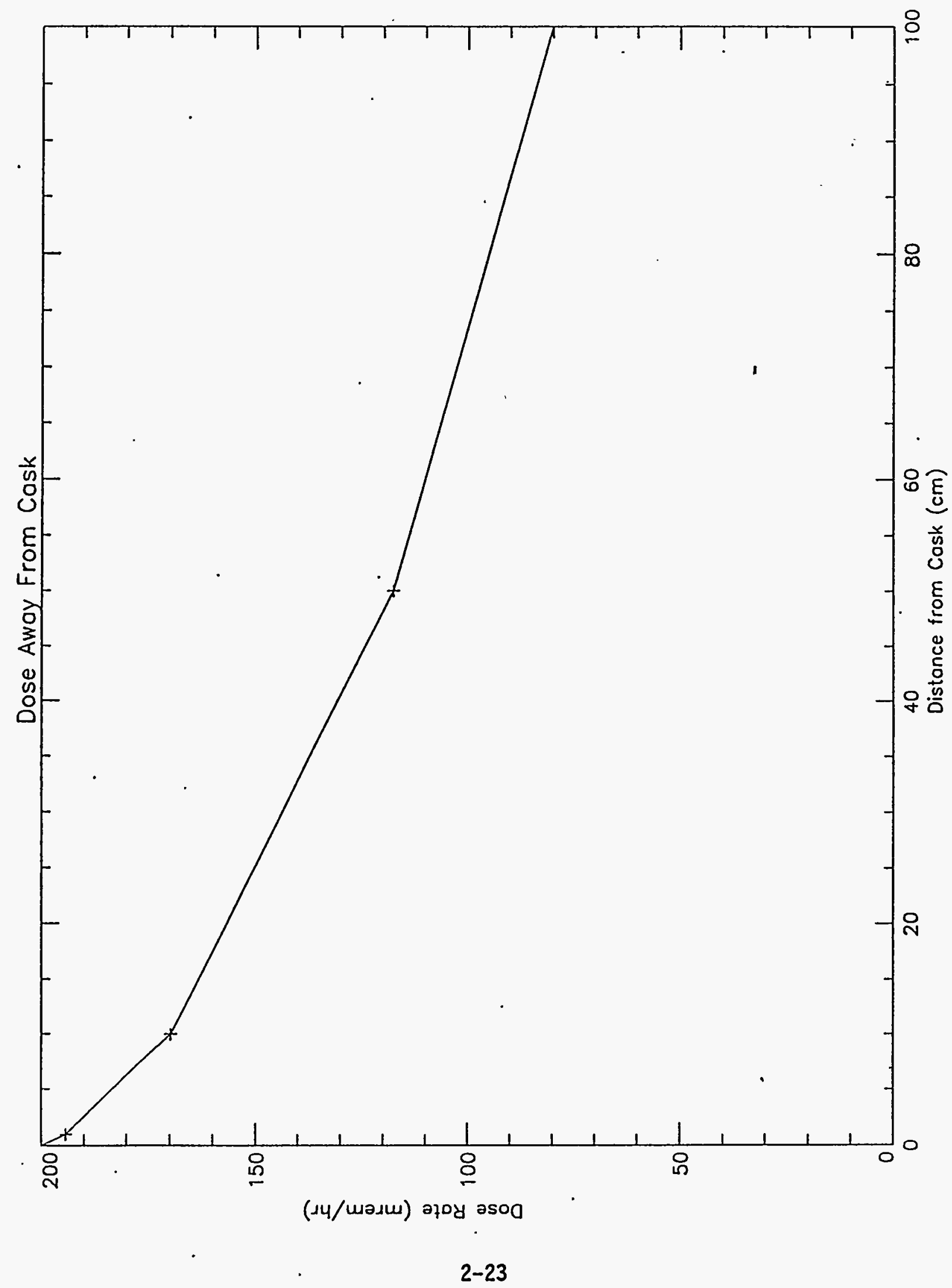


WHC-SD-W058-TA-001

Revision 0

cars and rail tanker cars, respectively. As stated in Section 1.2, the D\&D cost of the load/unload facilities (AGTS) as compared to the diversion boxes (UGTS) was assumed to be equal.

\subsubsection{Summary Cost Comparison}

The UGTS (buried pipe) has the lowest overall total cost for near term (1995 to 2005) and long term (1995 to 2028) as shown in Table 2-10. The UGTS higher initial project cost and final D\&D costs have been offset by the lower operational, evaporation, and radiation exposure costs which resulted in the lowest overall total cost.

For the near-term (1995 to 2005) waste transfer, the total lower estimated cost for buried pipe (UGTS) is $8 \%$ less than the rail tanker (AGTS) method. However, the percentage cost differential increases to $40 \%$ for nearterm and upper radiation exposure, $69 \%$ for long-term and lower radiation exposure, and $84 \%$ for long-term and upper radiation exposure as shown in Table 2-10. NOTE: The rail tanker system (AGTS) upper radiation exposure percentage is a higher cost than the buried pipe (UGTS) and is reduced from $40 \%$ to $25 \%$ for near term and from $84 \%$ to $78 \%$ for long term because of anticipated proper planning and managing of exposed personnel. Even though the rail tanker car method appeared to have the next lowest overall total cost for near term (i.e., approximately 49.509 million L [13.063 million gal] or less), the high radiation exposure to tank farm workers for routine operation is a concern for the long term.

The AGTS (trailer tanker car) has the highest total cost for near term (1995 to 2005) and long term (1995 to 2028) as shown in Table 2-10.

For the total Hanford Site cleanup (1995 to 2028), the UGTS is considerably less expensive (65\%) than any AGTS even without taking credit for radiation exposure cost as shown in Table 2-10. 
No

GIVEN

Total Eatimated Longht Of Procoss Pipe (17)* Buried Pipe:

Truck:

Required Transportation Vehical

Buriod Ppo:

Truck:

Rail:
64500 (Allspare)

3973 (1 spare)

3972 (1 spare)

0

$3\left(T \times 18^{\prime}\right)$

$2\left(12^{\prime} \times 44^{\prime}\right)$
COST PER UNIT

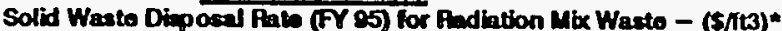

Buriod Pipo:

Truck:

Buriod Pipe Remove and Package Cost (\$/it)"

Buried Pipe:

Rail:

- See Appendix D - Dosign Calculation "Decommissioning Cost Comparison Bases," by D. V. Vo 2/10/95 ** The facility disposal cost is ASSUMED to be equal 
SUMMARY COST COMPARISON (1995 - 2005)

\begin{tabular}{|c|c|c|c|c|c|c|c|c|c|c|}
\hline Method & Project & Operation & Evaporation Cost ( $(3)$ & & on Exposur & re(\$) & Summary 080 & TOTAL & TIMATEDCC & OST (\$) \\
\hline & $\operatorname{cost}(\$)$ & $\operatorname{Cost}(\$)$ & (flush water) & Lower & Upper & Upper & Cost $(\xi)^{*}$ & Lower & Upper & Upper \\
\hline $\begin{array}{l}\text { Buried Pipe * } \\
\text { Truck } \\
\text { Rail }\end{array}$ & $\begin{array}{l}49228000 \\
34920000 \\
31920000\end{array}$ & $\begin{array}{r}8229690 \\
22076470 \\
22076470\end{array}$ & $\begin{array}{r}2106801 \\
28310134 \\
16130192\end{array}$ & $\begin{array}{r}0 \\
10450400 \\
5225200\end{array}$ & $\begin{array}{r}0 \\
94053600 \\
47026800\end{array}$ & $\begin{array}{r}0 \\
47026800 \\
23513400\end{array}$ & $\begin{array}{r}12123965 \\
1106321 \\
2468400\end{array}$ & $\begin{array}{l}71688455 \\
96863324 \\
77820265\end{array}$ & $\begin{array}{r}71688455 \\
180466524 \\
119621865\end{array}$ & $\begin{array}{r}71688455 \\
133439724 \\
96108465\end{array}$ \\
\hline Method & & & & & & & & $\begin{array}{l}\text { TOTAL COSTI } \\
\text { Lower }\end{array}$ & $\begin{array}{l}\text { EVIATION PE } \\
\text { Upper }\end{array}$ & $\begin{array}{l}\text { ECENTAGE (\%) } \\
\text { Upper } \\
\text { (with proper mgmt) }\end{array}$ \\
\hline $\begin{array}{l}\text { Buried Pipo } \\
\text { Truck } \\
\text { Rail }\end{array}$ & & & & & & & & $\begin{array}{r}0 \\
35 \\
9\end{array}$ & $\begin{array}{r}0 \\
152 \\
67\end{array}$ & $\begin{array}{r}0 \\
86 \\
34\end{array}$ \\
\hline
\end{tabular}

\section{SUMMARY COST COMPARISON (1995 - 2028)}

\begin{tabular}{|c|c|c|c|c|c|c|c|c|c|c|}
\hline \multirow[t]{2}{*}{ Method } & \multirow{2}{*}{$\begin{array}{l}\text { Project } \\
\text { Cost (\$) }\end{array}$} & \multirow{2}{*}{$\begin{array}{l}\text { Operation } \\
\text { Cost (\$) }\end{array}$} & \multirow{2}{*}{$\begin{array}{l}\text { Evaporation Cost (\$) } \\
\text { (flush water) }\end{array}$} & \multicolumn{3}{|c|}{ Radiation Exposure (\$) } & \multirow{2}{*}{$\begin{array}{l}\text { Summary DSD } \\
\text { Cost (\$)* }\end{array}$} & \multicolumn{3}{|c|}{ TOTAL ESTIMATED COST (\$) } \\
\hline & & & & Lower & Upper & $\begin{array}{r}\text { Upper } \\
\text { (with proper mgmt) }\end{array}$ & & Lower & Upper & $\begin{array}{r}\text { Upper } \\
\text { - (with proper mgmt) }\end{array}$ \\
\hline $\begin{array}{l}\text { Buried Pipe * } \\
\text { Truck } \\
\text { Rail }\end{array}$ & $\begin{array}{l}49228000 \\
34920000 \\
31920000\end{array}$ & $\begin{array}{l}126000000 \\
338000000 \\
338000000\end{array}$ & $\begin{array}{r}32256000 \\
433440000 \\
246960000\end{array}$ & $\begin{array}{r}0 \\
160000000 \\
80000000\end{array}$ & $\begin{array}{r}0 \\
1440000000 \\
720000000\end{array}$ & $\begin{array}{r}720000000 \\
360000000\end{array}$ & $\begin{array}{r}12123965 \\
1106321 \\
2468403\end{array}$ & $\begin{array}{l}219607965 \\
967466321 \\
699348403\end{array}$ & $\begin{array}{r}219607965 \\
2247466321 \\
1339348403\end{array}$ & $\begin{array}{r}219607965 \\
1527466321 \\
979348403\end{array}$ \\
\hline Method & & & & & & & & $\begin{array}{l}\text { TOTAL COST } \\
\text { Lower }\end{array}$ & $\begin{array}{l}\text { DEVIATION PE } \\
\text { Upper }\end{array}$ & $\begin{array}{r}\text { ERCENTAGE (\%) } \\
\text { Upper } \\
\text { (with proper mgmt) }\end{array}$ \\
\hline $\begin{array}{l}\text { Buried Pipe } \\
\text { Truck } \\
\text { Rail }\end{array}$ & & & & & & & & $\begin{array}{r}0 \\
341 \\
218\end{array}$ & $\begin{array}{r}0 \\
923 \\
510\end{array}$ & $\begin{array}{r}0 \\
596 \\
346\end{array}$ \\
\hline
\end{tabular}

- Decommision cost does not include the diversion box or laading/unloading facilities 
WHC-SD-W058-TA-001

Revision 0 .

\subsection{CONCLUSIONS}

The AGTS versus UGTS evaluation has resulted in the following specific and overall conclusions.

\subsection{SPECIFIC CONCLUSIONS}

1. A total of 13,063 trips (Table 2-1) are required to transfer the 49.509 million $L$ (13.063 million gal) of radioactive liquid waste in 11 years using the $3,800-\mathrm{L}(1,000-\mathrm{gal})$ capacity French truck. Based on the number of required trips, it is impractical and uneconomical to use the French truck system to routinely transport radioactive Tiquid waste from the 200 West Area to the 200 East Area and within the 200 East Area. Thus, the buried pipe system, trailer tanker. system, and rail tanker.system were the three methods selected for further evaluation.

2. The project (Table 2-2) and D\&D costs (Table 2-9) for AGTS and UGTS are fixed (that is, independent from the estimated total transfer volume). The UGTS requires higher project cost to go than the AGTS rail tanker system and trailer tanker system costs by $35 \%$ and $29 \%$, respectively. The final D\&D costs for the UGTS are $79 \%$ and $91 \%$ greater than the AGTS rail and trailer, respectively. NOTE: The initial project costs and final D\&D costs are the same to transfer either $3.8 \mathrm{~L}$ (1 gal) or 757.1 million $\mathrm{L}$ (200 million-gal).

3. The UGTS requires much less personnel support relative to the AGTS for the same capacities. Therefore, the UGTS buried pipe operational costs are $63 \%$ (for the near term) and $68 \%$ (for the long term) less than the AGTS rail tanker system and trailer tanker system, respectively. The operational cost details are shown in Tables 2-3 and 2-4.

4. The UGTS generates the least amount of secondary waste (flush water) in transferring of radioactive liquid waste (near term 49.509 million L [13.063 million gal] and long term 757.1 miltion L [200 million gal]) from the 200 West Area to the 200 East Area and within the 200 East Area. Because of 1 imited available double-shell tank space, generation of the radioactive liquid waste must be minimized. The evaporation cost comparison is shown in Tables 2-5 and 2-6. The UGTS buried pipe evaporation costs are approximately 8 times and 13 times less than the AGTS rait tanker system and trailer tank system for near and long term.

5. During routine transfer, there is essentially no personnel radiation exposure (ALARA) associated with the UGTS (buried pipe), whereas the AGTS total estimated radiation exposure is 2,090 man-rem (rail tanker car) and 4,180 man-rem (trailer tanker car) for near term as shown in Table 2-7. Because the Westinghouse Hanford Company Radiological Administrative Control Level is set at 5 rem/year per radiological worker (i.e., whole body) (WHC 1994), the estimated 
WHC-SD-W058-TA-001

Revision 0

radiation exposure equates to a yeariy average number of "burned out" personnel of 38 (rail tanker car) and 76 (trailer tanker car).

\subsection{OVERALL CONCLUSIONS}

1. The UGTS (buried pipe) has the lowest overall total cost for near term (1995 to 2005) and long term (1995 to 2028) as shown in

Table 2-10. The UGTS higher initial project cost and final D\&D costs have been offset by the least operational, evaporation, and radiation exposure costs which resulted in the lowest overall total cost.

2. The rail trailer system method (AGTS) appeared to have the next lowest overall total cost. However, the high radiation exposure to tank farm workers for routine operation is a concern for the long term and accident administrative control during transport of highlevel radioactive waste.

3. The AGTS (trailer tanker car) has the highest total cost for near term (1995 to 2005) and long term (1995 to 2028) as shown in Table 2-10.

4. For the total Hanford Site cleanup (1995 to 2028), the UGTS is considerably less expensive (65\%) than any AGTS even without taking credit for radiation exposure cost as shown in Table 2-10.

5. The risk assessment for the cross-site AGTS (Howden 1993) limited annual mileage for transporting radioactive sludge (without dilution) to $<400 \mathrm{~km}$ ( 250 miles)." The annual mileage limitation was set so that the accidental release frequency is considered incredible (i.e., $<10^{-6} / \mathrm{yr}$ ) without imposing administrative controls. The lowest demanded year for transport of liquid waste is 2003. The estimated total yearly (2003) transfer distance (roundtrip) is $1,019 \mathrm{~km}$ (637 miles) for rail tanker car and 2,782 km (1,739 miles) for trailer tanker car (Table 2-1). Rail tanker car and trailer tanker car roundtrips required travel distances that will have exceeded the yearly allowable AGTS 1 imit of $400 \mathrm{~km}$ (250 miles). Therefore, other stringent administrative controls (fire trailer escort, barricade road crossing, etc.) are required to increase the allowable mileage which will increase the operational cost.

*Note that the criteria for the Howden document were preliminary, and have since been formal7y documented in WHC-SD-TP-RPT-001 (Mercado 1994). A new risk assessment would be needed as part of any formal safety documentation (i.e., safety analysis report for packaging) for a selected AGTS. Therefore, actual mileage limits may be different than those presented here. 
WHC-SD-W058-TA-001

Revision 0 .

\subsection{TECHNICAL UNCERTAINTIES .}

\subsection{UGTS}

The buried pipe (UGTS) design is approximately $60 \%$ complete. The Preliminary Safety Analysis Report (Kidder 1993) revision and a system engineer design requirement document are being prepared. A7so, the environmental documentation for the UGTS is underway. The integrated Project W-058 is supporting the Tri-Party Agreement Operational Milestone M-43-07C of February 1998 as well. as other programmatic milestones. Thus, there is no technical uncertainty associated with the UGTS.

\subsection{AGTS}

The following technical uncertainties are associated with the AGTS. The preparation of the documents as described in Section 4.1 are required by DOE Order 4700.1, Project Management System (DOE 1987). However, these documents have not been prepared for the AGTS. The estimated cost associated with the AGTS Conceptual Design Report would be $\$ 200,000$ to $\$ 500,000$ and it would take about a year to complete. The estimated project cost for AGTS was based on preconceptual ideas. Conceptual Design, Title I (Preliminary Design), Title II (Definitive Design), and construction activities have not been started to meet the Tri-Party Agreement Operational milestone. This is the major uncertainty. Other technical issues, such as radiation exposure, additional accident administrative control during transport, a shielded $37,850-\mathrm{L}$ (10,000-gal) rail tanker car exceeding the rail truck loading requirements, remote operations (connect/disconnect), seismically qualified equipment, etc., all require resolution. 
WHC-SD-W058-TA-001

Revision 0

This page intentionally left blank. 


\subsection{REFERENCES}

Brantley, W. M., 1994, Functional Design Criteria for Project $W-058$, Replacement of Cross-Site Transfer System, WHC-SD-W058-FDC-001, Rev. 2, Westinghouse Hanford Company, Richland, Washington.

Brown, R. L., and C. J. Stephan, 1992, Cost Benefit Analysis at Westinghouse Hanford Company, WHC-SA-1533-FP, Westinghouse Hanford Company, Rich]and, Washington.

DOE, 1987, Project Management System; DOE Order 4700.1, U.S. Department of Energy, Washington, D.C.

DOE, 1989, Genera7 Design Criteria, DOE Order 6430.1A, U.S. Department of Energy, Washington, D.C.

Ecology, EPA, and DOE, 1994, Hanford Federal Facility Agreemerit and Consent Order, as amended, Washington State Department of Ecology,

U.S. Environmentai Protection Agency, and U.S. Department of Energy, 01ympia, Washington.

HanTon, B. M., 1994, Waste Tank Summary Report for Month Ending December 31, 1994, WHC-EP-0182-81, Rev. 0, Westinghouse Hanford Company, Richland, Washington.

Hansen, A. G., 1994, Tank Waste Remediation System Transfer Facility Compliance Plan, WHC-SD-WM-EV-094, Rev. 0, Westinghouse Hanford Company, Richland, Washington.

Howden, G. F., 1993, Pilot Plant Hot Test Facility Siting Study, WHC-SD-WM-TA-143, Rev. 0, Westinghouse Hanford Company, Richland, Washington.

Kidder, R. J., 1993, Preliminary Safety Analysis Report for Replacement of the Cross-Site Transfer System, Project H-058, WHC-SD-W058-PSAR-001, Rev. 0, Westinghouse Hanford Company, Richland, Washington.

Mercado, J. E., 1994, Report on Equivalent Safety for Transportation and Packaging of Radioactive Material, WHC-SD-TP-RPT-001, Rev. 0, Westinghouse Hanford Company, Richland, Washington.

Meng Analysis Group, 1994, Above Ground Transfer of Radioactive Liquids, Value Engineering Study, March 11, Meng Analysis Group, Seattle, Washington.

Smith, R. J., 1994, Packaging Design Criteria for the LR-56 Cask System, WHC-SD-TP-PDC-021, Rev. 0, Westinghouse Hanford Company, Richland, Washington.

Strode, J. N., 1994, Operational Waste Volume Projections, WHC-SD-WM-ER-029, Rev. 20, Westinghouse Hanford Company, Richland, Washington. 
WHC-SD-W058-TA-001

Revision 0

Toth, A. G., 1994, Double Shell Tank Inventory and Available Space (Memorandum to T. R. Sheridan., U.S. Department of Energy-Headquarters, December 28), U.S. Department of Energy, Richland Operations Office, Richland, Washington.

Trost, E. T., 1995, Personal Communication, Westinghouse Hanford Company, Richl and, Washington.

WHC, 1994, Hanford Site Radiological Control Manual, HSRCM-1, Rev. 2, December 9, Westinghouse Hanford Company, Richland, Washington. 
WHC-SD-W058-TA-001

Revision 0 .

.APPENDIX A

OPERATIONAL COST COMPARISON BASES 
WHC-SD-W058-TA-001

Revision 0

This page intentionally left blank. 


\section{WHC-SD-HO58-TA-001 \\ Revision 0 \\ DESIGN CALCULATION}
(1) Drawing
(2) Doc. No.
(3) Page $\geq$ of
(4) Building
(5) Rev.
(6) Job No.
(7) Subject OPERATIONAL COST COMBARISONI
(8) Originator drive us U. vo Date $221 /: 19:-$
(9) Checker
FlWAPS M. EPPEPCA Date

(10)

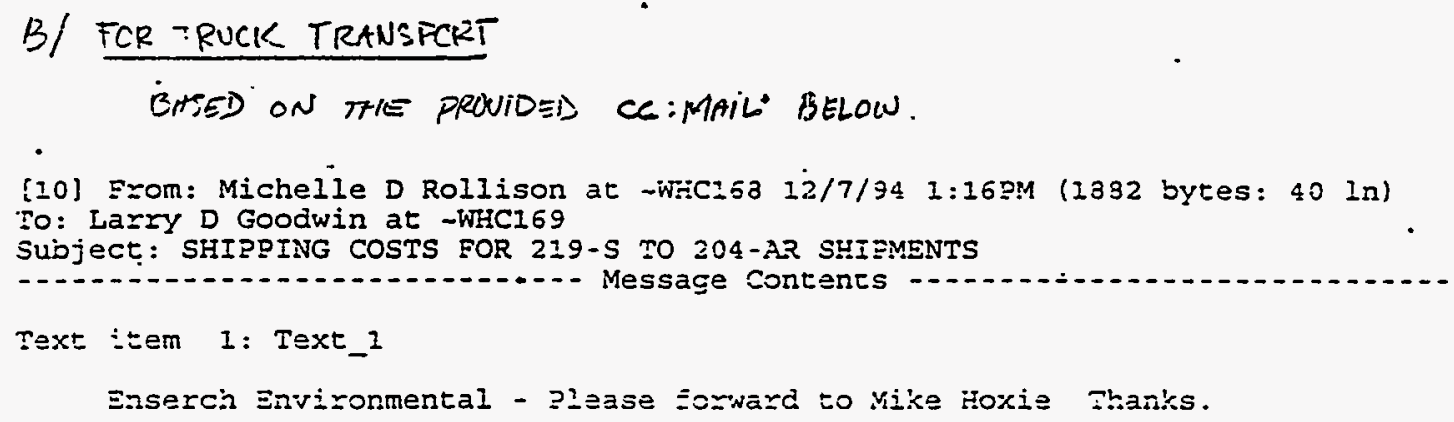

NoTE: The above estimated volume is within the range of $\$ 1: 40 / 9$ al to $\$ 2.00 /$ gal as listed ic the MENG valut Engr. reost (Page4). 
(1) Drawing (2) Doc. No. (3) Page $\Sigma$ of

(4) Building (5) Rev (6) Job No.

(7) Subject OPERATIONAL COST CMMPARISON.

(8) Originator Xquact: $V_{\text {V }}$ Date

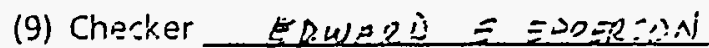
Date (10) C) FOR RAIL TRANSPORT BASED ON THE PRCUIDED CLIMAIL BELOW.

[55] From: Leonard $T$ (TY) Blackford at -WhC229 2/13/95 3:33PM (1113 bytes: 23 in )

To: Douglas V (Doug) Vo at - KEHIo

cc: Paul J Crane

SUDject: RAILCAR COSTS FOR TURNARAOUND

Doug;

Sorry for the delay but had trouble relocating data.

The following is a cost estimate for railcar turnaround at 221-T. This estimate was developed last year as part of a ECCEL item submitted when we received our ISD germit.

cost are for one time turnaround or one railcar:

Bargaining unit labor: $\$ 3379$ (192hrs)

Health Physics Labor: $\$ 1507$ (34 hrs)

Exempt Labor/Support: $\$ 2604$ (103 hrs)

Laboratory Analysis : $\$ 15,000$ (based on past costs)

Total costs per transfer: $\$ 23,090$

Approximately 2 transfers per year at this time.

Let me know if I can be of any further assistance:

I. Ty Blackford

Manager/ T plant Engineering

ESTIMATED OPERATIONAL COST FOR RMIL $=\$ 23,010 / 1,0000$ galions

$$
=2.30 / \text { gallon } 2
$$

NOTE: THE ESTIMATED OPERATIUNAL COST RANEE TH SHOWN INTHE MENG VALUE ENIR.

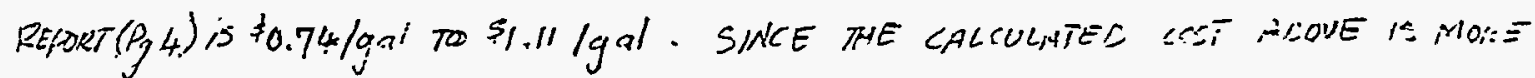
ACCURATE BUT OUTSIDE OF THE MENIT VALUE ENGR E'DTMIHTAD R'PNAE, THE ESTIMATED \&HL

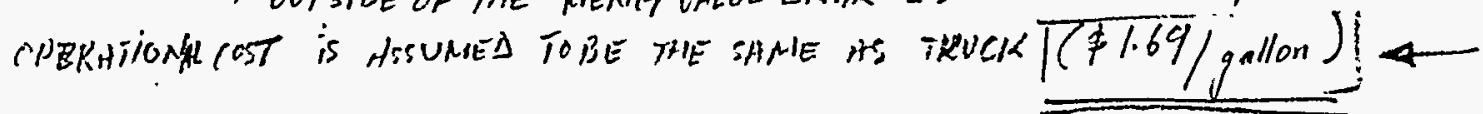




\section{WHC-SD-W058-TA-001 Revision 0 DESIGN CALCULATION}

(1) Drawing

(2) Doc. No.

(3) Page 4 . of

(4) Building

(5) Rev.

(6) Job No.

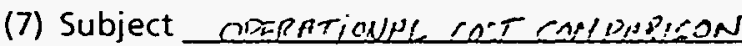

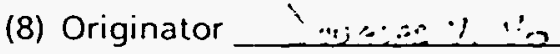

Date $22 / 19$ is

(9) Checker

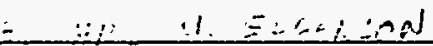
Date

(10). FOr cOMPHRI:ON, pelOW IS THE LISTED IPERATISNAL COST PER VOLUNE.

WESTINGHOUSE HANFORD COMPANY ABOVE GROUND TRANSFER OF RADIOACTIVE LIQUIDS

VALUE ENGINEERING STUDY

TRANSPORT LIQUIDS COST SUMMARY

ATTACHMENT II

\begin{tabular}{|c|c|c|c|c|c|c|c|c|}
\hline \multicolumn{9}{|c|}{ TRANSPORT LIQUIDS COST SUMMARY } \\
\hline \multicolumn{2}{|c|}{ OPERATHONAL COSTS } & & & \multicolumn{2}{|r|}{.LOW LEV } & & & PSRS \\
\hline & & $25 \mathrm{mi}$ & $10 \mathrm{mi}$ & ITANK & ITANK & & & PILOT \\
\hline & & RAIL & RAll & jTRUCK: & TRUCK I & CASK & PIPE & CASK \\
\hline FUNCYTION & GAL: & 19000 & 19000 & 5000 & $\quad 5000$ & 1000 & 1500000 & 7 \\
\hline \begin{tabular}{|l|l|}
$O A D$ & \\
\end{tabular} & & - & & & & & & \\
\hline PACKAGE UQUID & & $\$ 2000$ & 2000 & $3000:$ & 1500 & 1500 & 200000 & 6000 \\
\hline & & & & 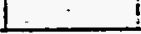 & $!$ & & & \\
\hline MOUNT CARRLAGE & & NA & NA & NA & NA & 500 & ind abv & inclobv \\
\hline MOVE & & & & & 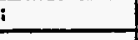 & & - &. \\
\hline MOVE CARRLAGE & (SECURIYY & 3000 & 3000 & $3000 i$ & & 3000 & incl obv & 3000 \\
\hline & (S per hr) & 1000 & 1000 & $250 !$ & 100 & 250 & & 250 \\
\hline & HIS & 14 & 10 & 41 & 4 & 4 & & 4 \\
\hline & TOT HRLY & 14000 & 10000 & 1000: & 400 & 1000 & NA & 100 \\
\hline \begin{tabular}{|l|l|} 
UNLOAD \\
\end{tabular} & & & & & - & & & \\
\hline UNLOAD CARRIAGE & & NA & INA & INA & iNA & 200 & inclabv & inclabv \\
\hline & & & & $i$ & 1 & $!$ & & \\
\hline EMPTY CONTAINER & & 2000 & 2000 & 3000 & 15001 & 2000 & linclobv & 2000 \\
\hline & & & & & & & & \\
\hline CLEAN CONTAINER & & indlobv & inclobv & ind & incl obv & incl abv & linclobv & 1200 \\
\hline \begin{tabular}{|l|l} 
REIURN & \\
\end{tabular} & & & & & & & & \\
\hline MOUNT CARRIAGE & & NA & NA & NA & :NA & neg & INA & neg \\
\hline & & & & & & & - & \\
\hline MOVE CARRIAGE & & NA & NA & NA & NA & 1000 & INA & 1000 \\
\hline & & & & & & & & \\
\hline UNLOAD CARRIAGE & & NA & NA & NA & NA & Ineg & NA & Ineg \\
\hline & & & & & & & & \\
\hline MAINI. CONTAINER & & inclobv & inclobv & incl cbv & incl abv & 5000 & 750000 & 7000 \\
\hline & & & & & & & & \\
\hline & & & & & & & & \\
\hline TOT per shipment & south of 1 & 21000 & 17000 & 10000 & 3400 & 14200 & 950000 & 21200 \\
\hline & north of w & 18000 & 14000 & 7000 & 3400 & 11200 & 950000 & 18200 \\
\hline spergal & south of W & \$1.11 & 50.89 & $\$ 2.00$ & 50.68 & 514.20 & 50.63 & $\$ 3.028 .57$ \\
\hline & north of w & 50.95 & 50.74 & 51.40 & 50.68 & $\$ 11.20$ & $\therefore 0.63$ & $\$ 2.600 .00$ \\
\hline & $a+3000 \mathrm{gd}$ & $57 . \infty$ & $\$ 5.67$ & & & & & \\
\hline
\end{tabular}




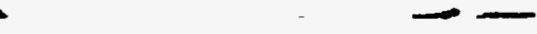

WHC-SD-H058-TA-00:

Revision óton

(1) Drawing

(2) Doc. No.

(3) Page 5 of

(4). Building

(5) Rev.

(6) Job No.

(7) Subject OPERATIONHL COST COMPAR:SON

(8) Originator Dovrila: V. Vo

Date $-\frac{1}{i}, \ldots-$

(9) Checker E-11.HRi; $M$. ETrE: Date

(10)

D/ OPERATIONAL COST EXHMPLE CALCULHTION

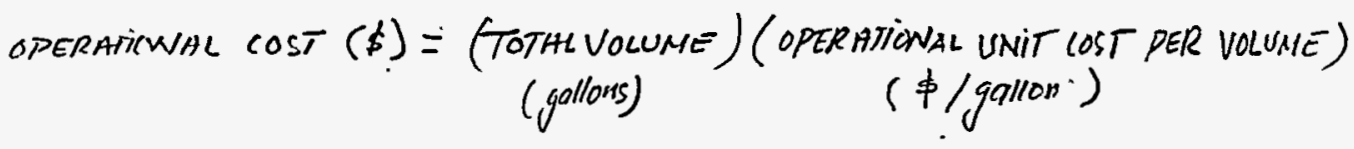

A-7

BD- $6400-060.1(12 / 87)$ 
WHC-SD-W058-TA-001

Revision 0

This page intentionally left blank.

A-8 
APPENDIX B

EVAPORATION COST COMPARISON BASES 
WHC-SD-W058-TA-001

Revision 0

This page intentionally left blank.

B-2 
(1) Drawing.

(2) - Doc. No.

(3) Page 1 of

(4) Building

(5) Rev.

(6) Job No.

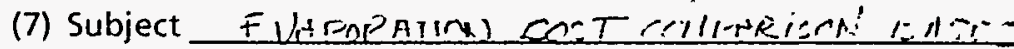

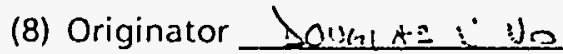
Date $=\operatorname{liniar}$

(9) Checker EMUIRT $\mu$ EPPER:AN Date

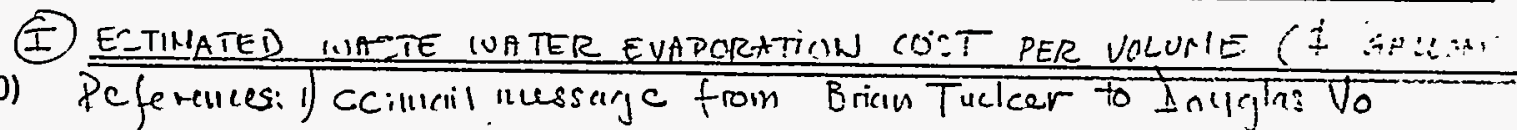

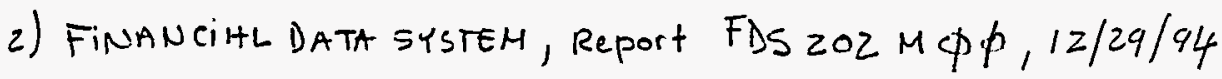

A) The evatoration cost Per voume is eetideen $\$ 3.21 / \mathrm{gal}$ to $\$ 6.21 \mathrm{gal}$. As DESCRIBED in Refereule 1 below.

[58] From: Brian J Tucker at WHC82 2/1/95 3:09PM (1132 bytes: 23 In) To: Douglas $\mathrm{V}$ (Doug) Vo at $\sim \mathrm{KEH} 16$ cc: Brian J Tucker Subject: Evaporator Cost Analysis Doug,

As we discussed over the phone this afternoon, I have estimated the cost per gallon to process waste through the 242-A Evaporator using current and projected budgets, and campaign waste volumes. The FY 96 waste volume is a somewhat reliable estimate provided by Tank Farms Engineering. The FY 97, 98, and 99 waste volumes are pure estimates.

IN1A budget/Volume treated = Cost per gallon

FY 95: $\$ 12.85 \mathrm{M} / 2.035 \mathrm{M}$ gallons $=\$ 6.31$

FY 96: $\$ 12.85 \mathrm{M} / 3 \mathrm{M}$ gallons $=\$ 4.28$

Cost per gallon in FY 97, 98, and 99 will be $\$ 3.21$ assuming $4 \mathrm{M}$ gallons processed per year and annual budgets of $\$ 12.85 \mathrm{M}$.

I hope this is helpful.

Brian Tucker 


\section{WHC-SD-W058-TA-0O1 \\ Revision 0 \\ DESIGN CALCULATION}

(1) Drawing

(2) Doc. No.

(4) Building

(5) Rev.

(3) Page z of

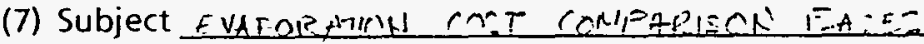

(8) Originator JAurtcti $U$. Vo

(9) Checker

EDiaris M. EDAER:AN

(6) Job No.

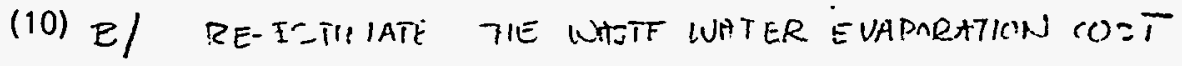

- there are two canifaicins planined in fy 1995. the first chapainen WHS DONE ON $1 / / 94$ JUITH.THE DOTHL EVHPORATE VLLUMES OF 2.79 . FALLONS AND THE NEXT CAMPAITN IS SCHEDULED FOR $06 / 15$ WITI A TARTET EVAPORATION VOLUHE OF 2.04 RAHLONS. PAGE 3 IS THE DETAIL CC:MAIL MESSAGE FROM THE $242-A$ EUAPORATOR PROCESS ENGINEER (ELVIS LE).

- EXPECTEDFYRIS- FUNDING FCR THE $242-A$ EVAFORADUR is $\neq 12,174,000$ Activity /

CM

CM

FYTD

CM
ACTUALS VARIANCE

BUDGET

FYTO

FYTD

CURRENT FY EXPECTED FY

ACTUALS VARIANCE

FAR HR
ST
$\mathbf{\$}$
GA/CSP

19,803

117.2

$1,201.5$

182.7

15,617

-.........

BUDGET

$\begin{array}{lll}89.8 & 27.4 & 122.5\end{array}$

$1,003.8$

165.5

TOT $s$

$1,384.2$

$1,169.3$

\begin{tabular}{rr}
197.7 & $4,479.9$ \\
17.2 & 744.4 \\
\hline & $7 . .2$
\end{tabular}

56,051

VARIANCE

BAC

FUNDS

$\begin{array}{rrrr}91.0 & 31.5 & 119.9 & \ldots\end{array}$

$\begin{array}{rrrr}3,277.4 & 1,202.6 & 13,433.9 & 12,174.0\end{array}$

$\begin{array}{rr}9 & 3,277.4 \\ 569.4\end{array}$

175.0

$3,846.7$

$1,377.6$

$2,115.5$

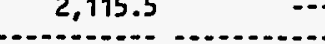

$15,549.4 \quad 12,174.0$

$\therefore$ Re-ESTIMATED EVAPORATICN COET $(7)=\$ 12,174,000 / 4,830,000$ i allon:

$$
\text { EETIMATED EVATORATION } \cos T(7)=72.52 / \mathrm{gallons}
$$



(1) Drawing
(2) Doc. No.
(3) Page 3 of
(4) Building
(5) Rev.
(6) Job No.

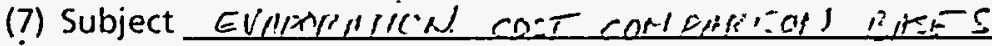

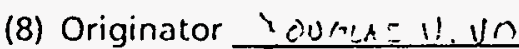

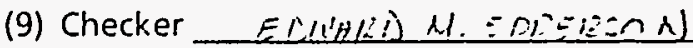 Date Ello/gi- Date

(10) BELON is THE ACTLAL IUASTE VOLUME REDUCTION INTORMIATION FOR FY 94 i 95.

[70] From: Elvis Q Le at WHC338 2/9/95 12:41PM (1793 bytes: 33 In)

To: Douglas $V$ (Doug) Vo at $-\mathrm{KEH} 16$

cc: Elvis Q Le

Subject: Evaporator Campaigns 94-95

Per yoursage Contents

Per your request, I am writting to summarize our ealier conversation regarding to Evaporator Campaigns 94-95.

Campaign 94-1 took place between April 15 and June 14, 1994. From an available 2.87 million gallons of dilute waste contained in 102-AW, 106-AW and 103-AP, an overall Waste Volume Reduction (WVR) of 2.39 million gallons (83\% WVR factor) was achieved. The post-run document (WHC-SD-WM-PE-053, Rev.0) was issued on September 30,1994 to summarize the results of 242-A Evaporator Campaign 94-1 as required per WHC-IP-0842 Section 8.12 , subsection 6.2 "Process Evaluation Report".

Campaign 94-2 was started on September 22, 1994 and completed on November 19, 1994. Approximately 3.21 million gallons of dilute waste from 101-AP, 107-AP, 108-AP and tank heels from 102-AW and 106-AW were processed, achieving the WVRF goal of $87 \%$ (2.79 million gallons). A post-run document is currently being prepared to fulfill WHC-IP-0842 requiremement of "Process Evaluation Report".

Campaign 95-1 start-up date is presently scheduled on June 1, 1995. Approximately 2.43 million gallons of dilute waste from 106-AP, 107-AP, and 106-AW will be processed. Based on a preliminary projection, a WVF of 2.04 million gallons can be achieved.

Campaign 96-1 is tentatively scheduled on October 1, 1995. About 830,000 gallons of dilute complexed waste from 101-AY will be processed. Based on its unique characteristic in nature, it is projected that a WVF of 620,000 gallons can be achieved.

Please let me know if I can be futher of assistance.

Elvis Le

242-A Evaporator 


\section{WHC-SD-H058-TA-001 \\ Revision 0 \\ DESIGN CALCULATION}

(1) Drawing

(2) Doc. No.

(3) Page 4 of

(4) Building

(5) Rev

(6) Job No

(7) Subject EIHPORATION CIET COMIPHEIOON BHEES

(8) Originator $\because \cdots, \ldots=.^{\circ}, \because$

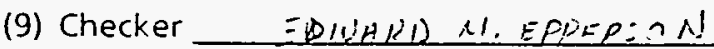

Date

(II) ESTIMATED FLUSH VOLUNE

1) TRANSFER TANK 102 LIQUID IUH:7E TO TANK FAPM "LO-100-160"

2) PERFOPM LIQVUD WAJTE TRANSFER TROM TANK 15-1 TO PAIL CAR SN RHILTUNNEL "T0-100-029" REV FII

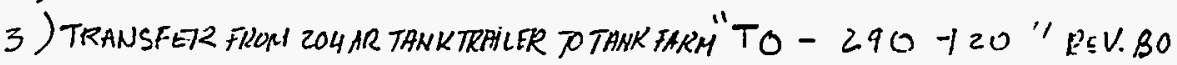

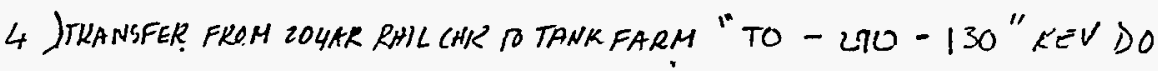

5 I r POSS SITE TRANSFER FROCEDLRE 102ST tO $103 \mathrm{AZ}, 101 \mathrm{AN}$,

103 - AN, OK 102-S, VIA 244-5 "TO-025-070" EEV.A-13

6) WUSTE TEANSFER LINE PREHEATING CHLCULATION " $w-058-023$ " $12 / 1 / 4$ ?

A) CROSS-SITE TRANSFER FLUSH WNTER GENTRATION EETIMATEd UOLUME

PulRIED PIPE ESTIMATED VOLUHE (gallons) = PREHEAT (Ref 5 ) + FLUSH (Reg 6 )

$=12000$ gallons $+20,000$ gallons

$=32,000$ gallons +

B/ RAIL/TRUCK CAR FLUSH WATER.

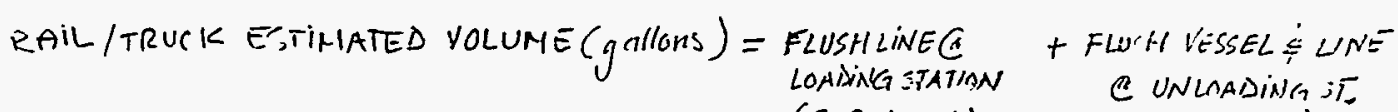
(Reg.loR2) (Xef $3 n 4)$

$\rightarrow$ RAIL EAIMATED VCLUNE (gallons) = 350 gallonst ( 2100 gallans) (FOR DECON WASTE)

$=2450$ grillons

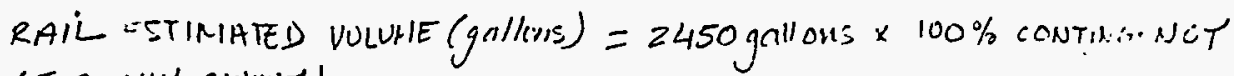
(FOR +ILW SLUKRT)

$$
=4900 \text { gallows }
$$

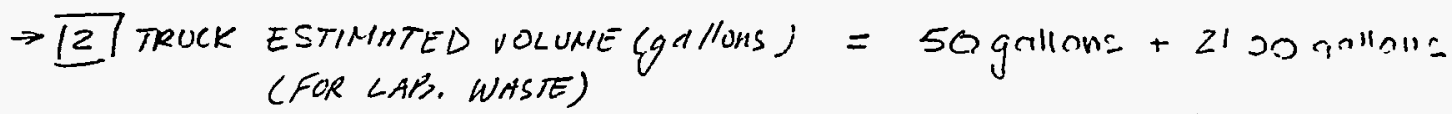

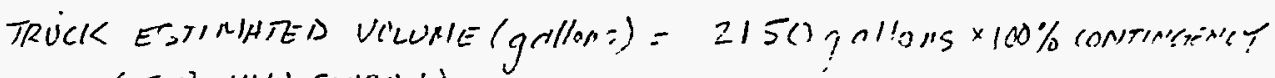

$$
\text { (FOR HLW =LURRT) }
$$

$$
=4200 \text { in'in: }^{\prime \prime}
$$

(III) EVHPORHTION COST EXAMIPLE CALCOCHTION

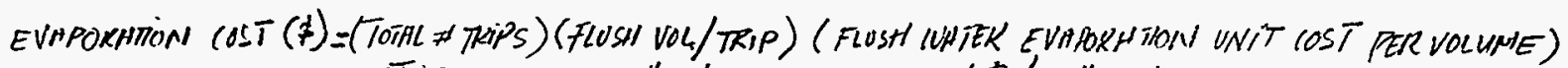

(Trip) 
WHC-SD-W058-TA-001
Revision 0

APPENDIX C

RADIATION EXPOSURE COST COMPARISON BASES

C-1 
WHC-SD-W058-TA-001

Revision 0

This page intentionally left blank. 


\section{WHC-SD-W058-TA-001 \\ Revision 0 \\ DESIGN CALCULATION}
(1) Drawing
(2) Doc. No.
(3) Page 1 of
(4) Building
(5) Rev.
(6) Job No.

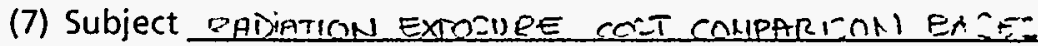
(8) Originator

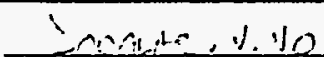
(9) Checker

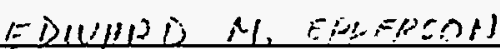
Date $=21: y / 15$ Date

(10) REferchecs:

1) FUNCTONHL DESIGN CRITERIA FOR PROJECT W-OSB, REPLACEMENT OF CROSS-SITE TRANSFER SYITEH, by W.M.Brantley, WHC-SD-WOS8-FDC-0OI, ReV. 2, 08/26/94.

2) PACKAGING DESIGN CRITERIA FCR THE LR-56 CASK SYSTEM, bY R.J.SHITH, WHC - SD TTP -PDC-OZI, REV. $\phi, 03 / 15 / 94$.

3) SHIPPING COSTS FOR 219-S TO 204 -AR SHIPMENTS, CG:MOII FROM M.D,ROLLISON TO LID. GOODLUIN, 12/07/94. (STE OPERATIONAL COST COMPARISON IATES CALCULHTION TOR DETAIL).

(A) NUMEER OF HIPT REQUiRED TO SURUEY

1) fER telEPHONE CONFEILENCE BETWEEN D.V.VO HND T.K. RAVENCRHFT, It WAS INAICATED THATT 2 HPTS HRE PERFORMED KHDIOLOGICAL SURVET FEFIIE. THE LIQUID IUASTE GET UNLOAD AND ALLOW THE RAIL OR TRUCK LEAUIA'T THE FACILITIES.

$$
\therefore 2 \text { HIPTs FOR RAIL/TRUCK }
$$

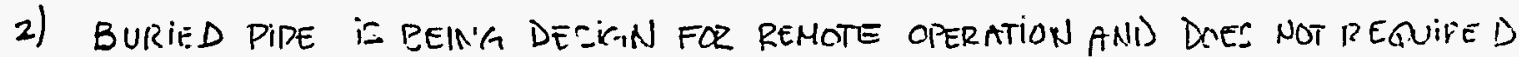
RABIOLOGICAL SURVET.

$$
\therefore \phi \text { HIPTS FOR ISURIED PIPE }
$$

(B) REFERELE 3 SHLWS TOTAL IE HCURS OF HPT SUPPORT

$$
\therefore \text { estimated Radiologkal surver tille = EHOURS/TRansFEz }
$$

(c)

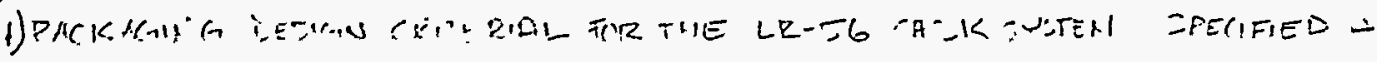

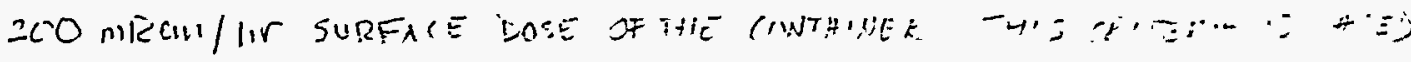

$$
\begin{aligned}
& \text { ON DEPAKTIIENT OF TRANSPORTATION REGULATION } 49 \text { CFR PART 173.44\%. } \\
& \therefore \text { FOR HIGH LEVE WASTE TRANSPORTER SURFHCE dOSE }=200 \mathrm{mR} \mathrm{cm} / \mathrm{hr}
\end{aligned}
$$


WHC-SD-W058-TA-001
Revision O

DESIGN CALCUI.ATION

(1) Drawing

(2) Doc. No.

(3) Page 2 of

(4) Building

(5) Rev.

(6) Job No.

(7) Subject RHDATION EXPRIIEE COTT COMPARI:ON DNSES

(8) Originator Douala? V Vo

Date $12110 / 1 \%$

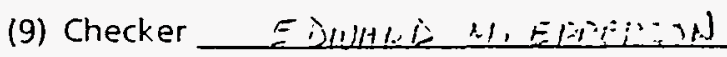
Date

(10)

2) REFERENCE I SPECIFIED tHE sURFACE dOSE FOR PURRED PIPE ;Y:TEM TO RE C.OSnRem/hr

Ra diation exposure cost exthiple calculation

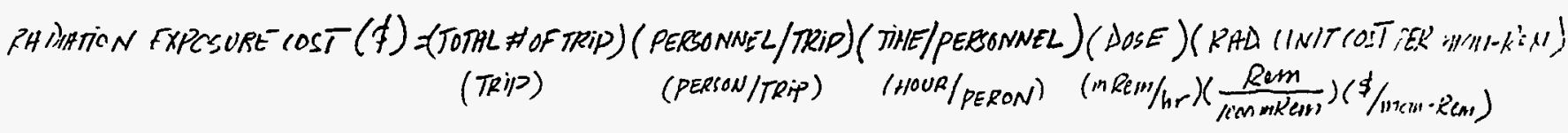

C-4

BD-6400-060 $1(12 / 87)$ 
HHC-SD-W058-TA-001

Revision 0

APPENDIX D

DECOMMISSIONING COST COMPARISON BASES

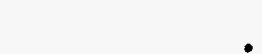


WHC-SD-W058-TA-001

Revision 0

This page intentionally left blank. 
(1) Drawing

(2) Doc. No.

(4) Building

(5) Rev.

(3) Page 1 of

(7) Subject DeCOMMISSIONING COST COMPARISON BASES

(8) Originator Naglas lo

(9) Checker

EDWUARI $A T=20 E R \leq 0 \mathrm{~N}$ Date

(6) Job No.

(10) $i$ ABOUEgROUND TRANSPORTATION ESTIMATED QUANTITIES AND COST FoR $\Delta$ \&D

(I) PROCESS PIPING FROM ZOLAR TO VALUEFIT ZLI-A-A ( 3 "\$ST $\times 6^{\prime \prime}$ " C's EvG.)

References: $5 K-2-4263 \& 6430$. IA

Lenght (East-west) : $w_{47764.50-w_{4}} 4124.17=360^{\prime}$

Lenght (North South) :(N41136-N41040)Z $=192^{\prime}$

Lenght (INSIDE BLDG-20\%):

$110^{\circ}$

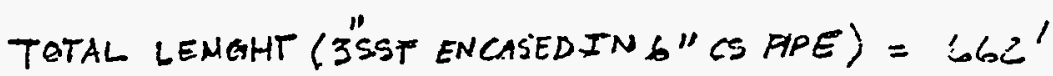

SPAREFOR SLURRY TRANSPORT $(6430.1 A-1323-5.2)=662^{\prime}$

$$
\text { Process piping }=1324 F
$$

TOTAL PROCESS PIDING $=2648$ FT FOR JFACIIITIES:-

(II) TRUCK/RAIL TRAASPORTER

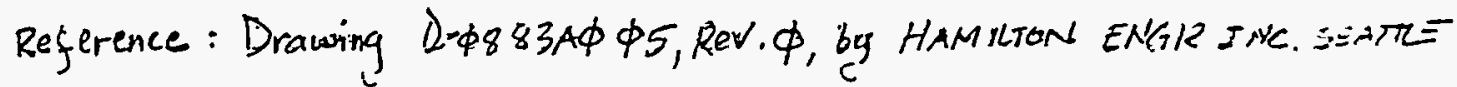
H SSUMPTION: 1) RAIL GAR CHA BE DISPOSED AS A WHOLE.(SAME FOR TRUCK)

2) NO PACKAGING is REQUIRED TO diSPOSE OF A RADIOACTIVE MiXESWASTE RAIL CAR (SAHEFOR TRUCK)

3) THE HIGHLEVEL LIQUii) WASTE RAIL UAR WILL HAVE THE SHME DIMENSION AS THE DESIGNED DOUBLE-WALLED CONTAINMENT LOW LEVEL LUQUID WASTE RHIL CAR (WITIOUT SHELLING )- (S,HE FOR TRUCK-)

RAILCAR DECOMMISSTON COST $(\$)=$ PACKAGE COST $(\$)+$ DISPOSED COST $(\$)]$

$$
\begin{aligned}
& =\phi+(\text { AREA)(LENGHT) (RMW DISPOSE RAIE) } \\
& =\phi+\left(\pi \times 6^{\prime 2}\right)\left(44^{\prime}\right) \cdot\left(\$ 173 / F T^{3} .\right. \\
& =\$ 860,397 / \text { RALCA-IE }
\end{aligned}
$$

TRUCK CAR DECOMMISSION COST $(\$)=\phi^{2}+\left(\pi \times 3.5^{\prime 2}\right)(13)\left(\$ 77^{3} ; 5^{3}\right.$;

$$
=\$ 119841 / \text { TKUCK CAR }
$$




\section{DESIGN CALCULATION}

(1) Drawing

(2) Doc. No.

(4) Building

(5) Rev.

(3) Page ?

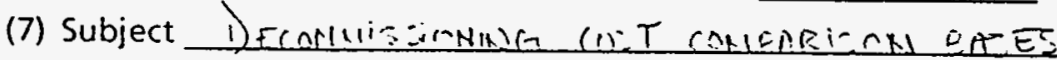

(8) Originator $\because 4: 4=1.10$

(9) Checker $\because, P M, M P Q E R E A N$ Date Date

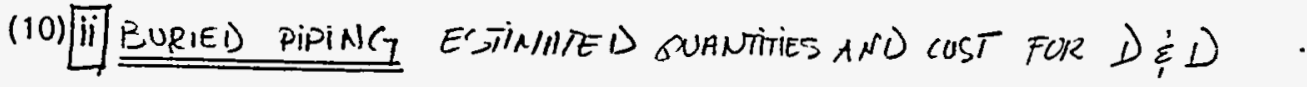

(I) PROEESS PIPING FROM ST TANK FARM TO 244 A-LIFT G' 51 AR (WOSO : WOZZ')

A/ FOR WOS8 - Refciences: TITLE I COST EJTIMATE, 08/05/93, W05:PAA5 CHANGE" REQUEST IN-OS8-036 ReV. $\phi$, APPROUED 9/15/45 PITING SPOOL (3"IST $\times 6^{\prime \prime} \mathrm{C} / \mathrm{S}$ ENCASEMENT) $=68390^{\circ}+2000^{\circ}+5642^{\prime}=76032^{\prime}$ UENT LINE REMOVE PER CR-036 $=.14100^{\prime}$

$\therefore$ TOTAL IVOS8 EETIRMTED DIDING SPOOL $=61432^{\prime}$

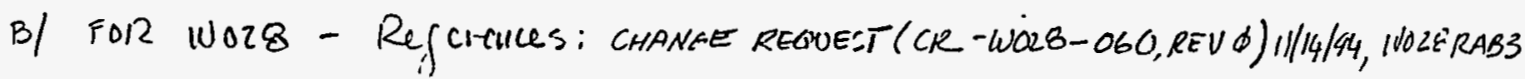
PIPING SDOOL (3"SST $\times 6^{\prime \prime} \mathrm{C} / \mathrm{S}$ ENCNEEMENT) $=900^{\prime}+11000^{\prime}+1430=13830^{\prime}+$

c/ TOTAL PIPING SPOOL FOR BOTH WO58 AND wO2E $=75762^{\circ}$

(II) E-TIMATED TOST FOR PIDING REMIOUED AND PACMAGE FOR BURIED GIRECMID

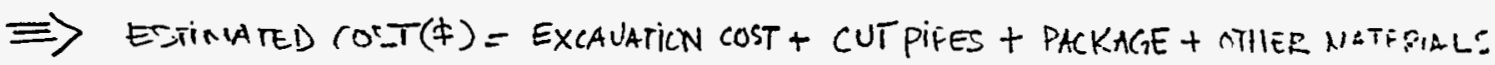
A) EXCAVATION COST $(7)=$ MACHINE (First fair feet) + HAND (Last 2 Feet $)+$ BACKFILL
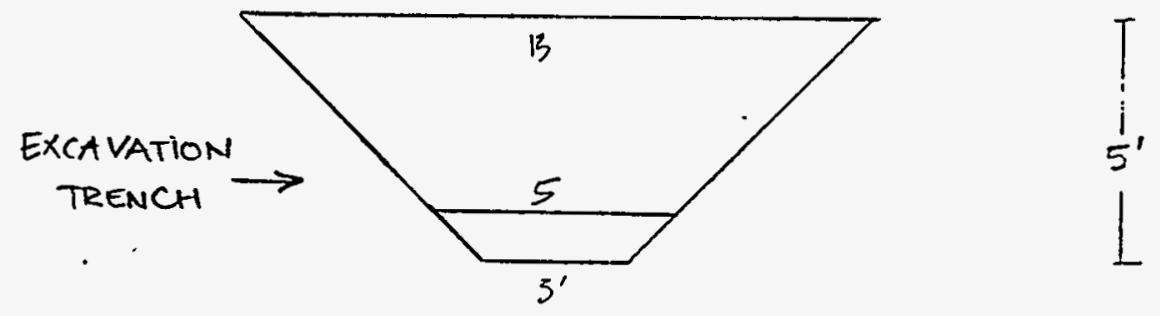

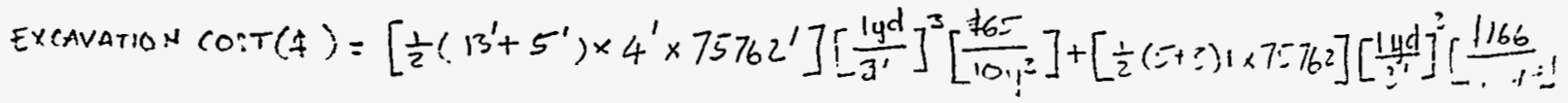
$=765 \div 604+71363184+76=1-604=1279,79 \% 17=2$ 


\section{WHC-SD-W058-TA-001 \\ Revision 0 \\ DESIGN CALCULATION}

(1) Drawing

(2) Doc. No.

(3) Page 3 of

(4) Building

(5) Rev.

(6) Job No.

(7) Subject

(8) Originator

(9) Checker

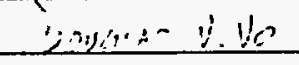

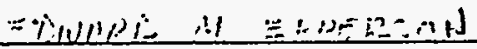

Date

Date

(10)

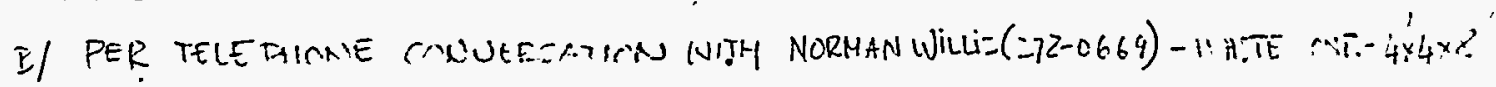

CUT PIPES COST $(\$)=$ (TOTAL\# OT CUT) (TIME/CUT) (\$/TIME) (\# OF LAPOR)

$$
=(75762 \% 1 / \text { CUT } '(2 \text { HOURS/CUT })(\$ 50 / \text { HRS })(3)=\$ 2,841,075
$$

- The three laeors are: 2 pipe fitter, I hPT

C) PACKAGE THE CUT UP SECTION IN THE IOLID WA:TE CONTAINER (INK. FILLVOII)

$$
\operatorname{PACKAGE} \cos (\$)=\left(75762 \% / \mathrm{s}^{\prime} / \mathrm{CUT}\right)(1 \text { HOURS } / \text { CUT })(\$ 50 / \mathrm{HRS})(;)=\$ 1,420,537
$$

D/ OTHER MHITERIALS

MATERIALS COST $(\neq)=$ CUER PACK CONTAINER + FRESH HIR + MINST +TOOLS + UTHER $=\left(\frac{94705 E T I C N 5}{325 E C . / 130 X}\right)(2000 \$)+\beta 300,000+\$ 100,000$ $=\$ 991,840$

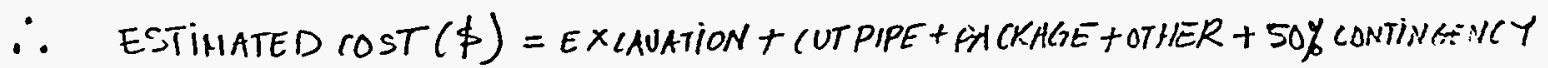
$=\frac{1}{2}, 5,9,788+52,841,075+F 1,420,338+991,390+3,886,645$ RENIOUE SPACKATE EST. COSI $(\$)=\$ 11,659,936$ FOR $75762^{\prime}$ CF APE

REMOUE $:$ PACKAGE EST.COET PER LINEAK FOOT $=$ t/54/FT d 
(1) Drawing

(4) Building

(7) Subject

(8) Originator

(9) Checker

(2) Doc. No.

(5) Rev.

(6) Job No

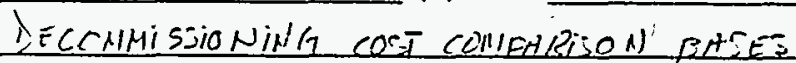

(3) Page 4 of

(10) Iii) FROH FORREST DHY (ICF-KH ESTMIATSR) THE TAMLE PELON WAS ARTAINEA

Eor five year planning purposes, Solid haste programs estimates the FY95 - FY99 S.torage Disposal Rates as Follows:

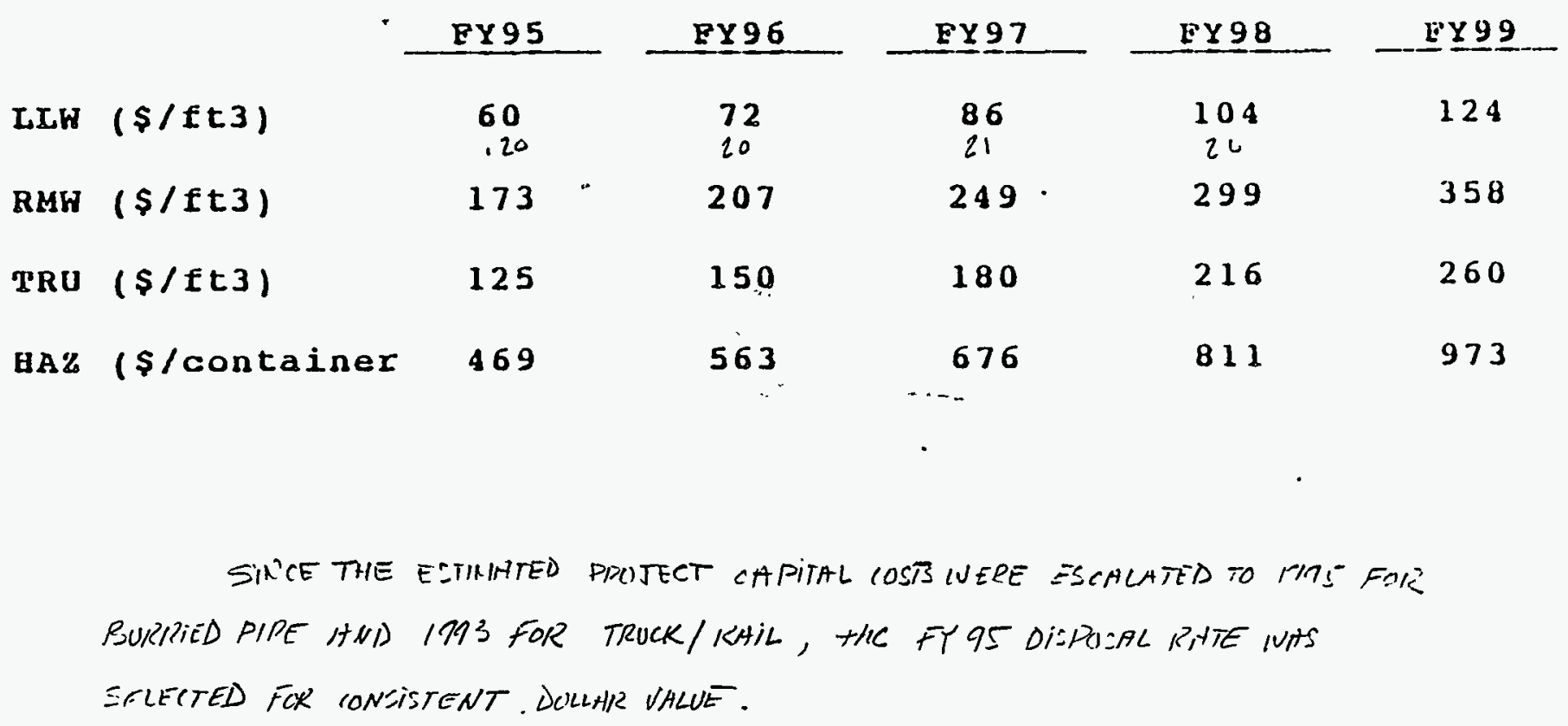

[iii) DECOMMISSIONING COST EXAMPLE CALCULATION

REMOVAL COST $(q)=$ PIPE $=($ TOTIL LENGHT) (BURIED PIPE REROUAL $\&$ PACRAGE IINIT TOST) (feet) $(\$ /$ foot $)$

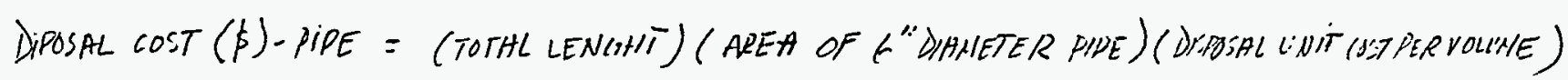

$$
(f t) \quad\left(f^{2}\right) \quad\left(f / t^{3}\right)
$$

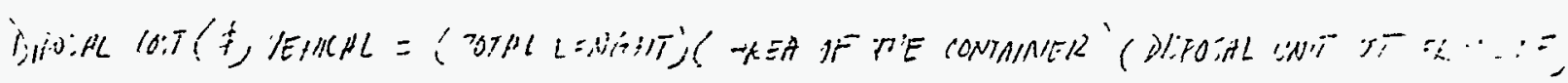

